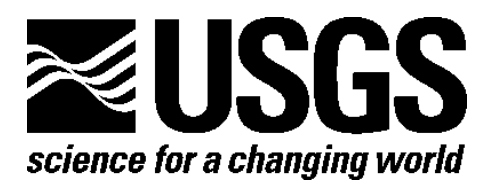

\title{
Constraining the Location of the Archean-Proterozoic Suture in the Great Basin Based on Magnetotelluric Soundings
}

By Brian D. Rodriguez and Jay A. Sampson

Open-File Report 2012-1117

U.S. Department of the Interior

U.S. Geological Survey 


\title{
U.S. Department of the Interior \\ KEN SALAZAR, Secretary
}

\author{
U.S. Geological Survey \\ Marcia K. McNutt, Director
}

U.S. Geological Survey, Reston, Virginia: 2012

For more information on the USGS-the Federal source for science about the Earth, its natural and living resources, natural hazards, and the environment-visit http://www.usgs.gov or call 1-888-ASK-USGS

For an overview of USGS information products, including maps, imagery, and publications, visit $h$ ttp://www.usgs.gov/pubprod

To order this and other USGS information products, visit http://store.usgs.gov

Suggested citation:

Rodriguez, B.D., and Sampson, J.A., 2012, Constraining the location of the Archean-Proterozoic suture in the Great Basin based on magnetotelluric soundings: U.S. Geological Survey Open-File Report 2012-1117, 30 p.

Any use of trade, product, or firm names is for descriptive purposes only and does not imply endorsement by the U.S. Government.

Although this report is in the public domain, permission must be secured from the individual copyright owners to reproduce any copyrighted material contained within this report. 


\section{Contents}

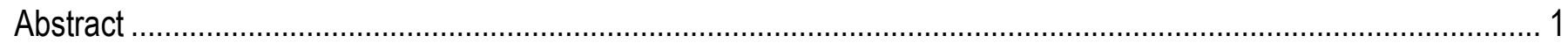

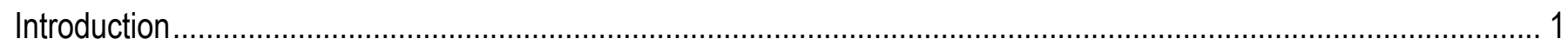

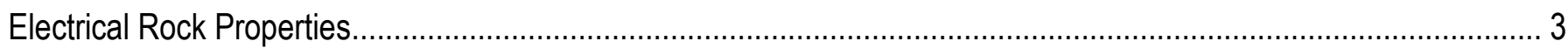

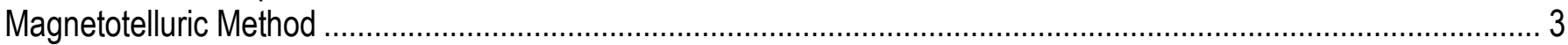

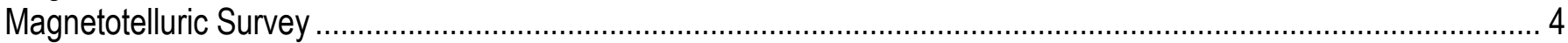

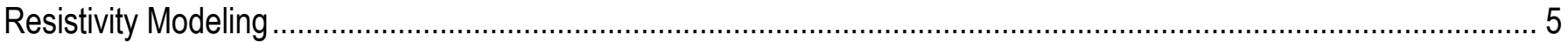

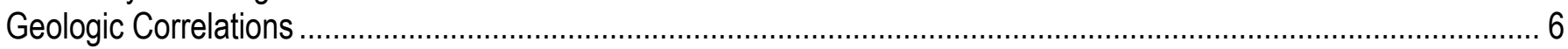

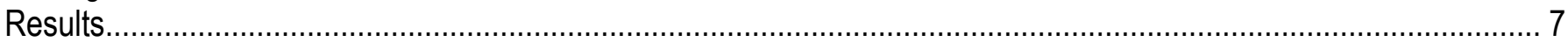

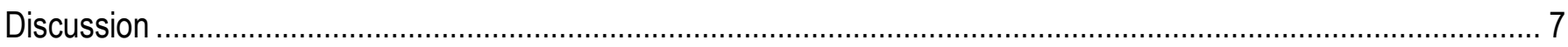

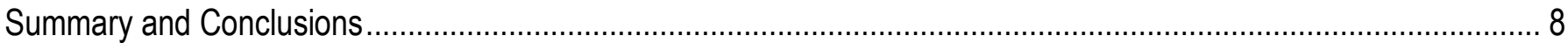

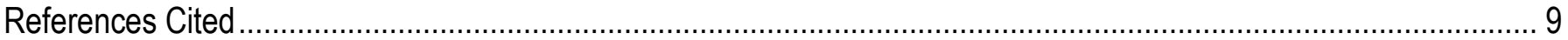

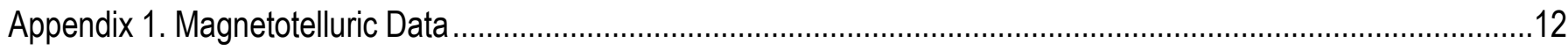

\section{Figures}

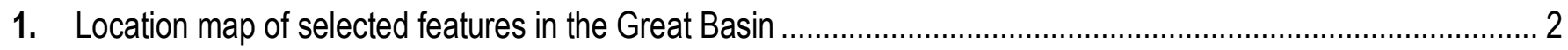

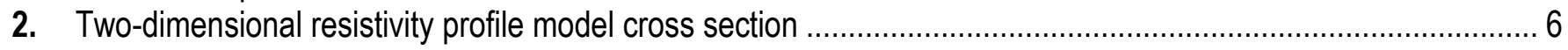

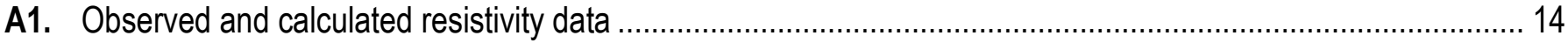

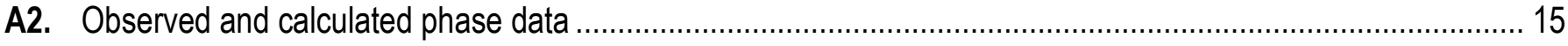

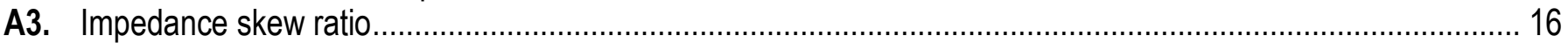

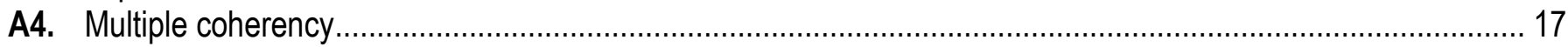

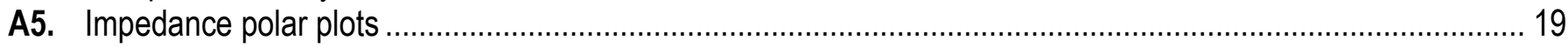

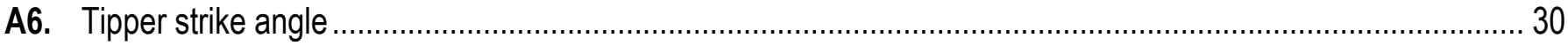

\section{Table}

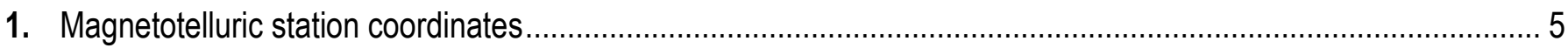




\section{Conversion Factors}

Inch/Pound to SI

\begin{tabular}{lcl}
\hline \multicolumn{1}{c}{ Multiply } & By & \multicolumn{1}{c}{ To obtain } \\
\hline foot $(\mathrm{ft})$ & Length & \\
mile $(\mathrm{mi})$ & 0.3048 & meter $(\mathrm{m})$ \\
mile, nautical (nmi) & 1.609 & kilometer $(\mathrm{km})$ \\
yard $(\mathrm{yd})$ & 1.852 & kilometer $(\mathrm{km})$ \\
\hline
\end{tabular}

SI to Inch/Pound

\begin{tabular}{lcl}
\hline \multicolumn{1}{c}{ Multiply } & By & \multicolumn{1}{c}{ To obtain } \\
\hline meter $(\mathrm{m})$ & Length & \\
kilometer $(\mathrm{km})$ & 3.281 & foot $(\mathrm{ft})$ \\
$\operatorname{kilometer}(\mathrm{km})$ & 0.6214 & mile $(\mathrm{mi})$ \\
meter $(\mathrm{m})$ & 0.5400 & mile, nautical $(\mathrm{nmi})$ \\
\hline
\end{tabular}

Vertical coordinate information is referenced to the 1866 Clarke Spheroid.

Horizontal coordinate information is referenced to the North American Datum of 1927 (NAD 27).

Elevation, as used in this report, refers to distance above the vertical datum. 


\title{
Constraining the Location of the Archean-Proterozoic Suture in the Great Basin Based on Magnetotelluric Soundings
}

\author{
By Brian D. Rodriguez and Jay A. Sampson
}

\begin{abstract}
It is important to understand whether major mining districts in north-central Nevada are underlain by Archean crust, known to contain major orogenic gold deposits, or, alternatively, by accreted crust of the Paleoproterozoic Mojave province. Determining the location and orientation of the Archean-Proterozoic suture zone between the Archean crust and Mojave province is also critical because it may influence subsequent patterns of sedimentation, deformation, magmatism, and hydrothermal activity. In the Great Basin, the attitude of the suture zone is unknown because it is concealed below cover. A regional magnetotelluric sounding profile along the Utah-Nevada State line reveals a deeply penetrating, broad electrical conductor that may be the Archean-Proterozoic suture zone in the northwest corner of Utah. This major crustal conductor's strike direction is northwest, where it broadens to about $80 \mathrm{~km}$ wide below about $3-\mathrm{km}$ depth. These results suggest that the southwestern limit of intact Archean crust in this part of the Great Basin is farther north than previously reported. These results also suggest that the major gold belts in north-central Nevada are located over the Paleoproterozoic Mojave province, and the Archean terrain lies northeast in the northwest corner of Utah. Rifted Archean crust segments south and west of the suture suggest that future mineral exploration northeast of current mineral trends may yield additional gold deposits.
\end{abstract}

\section{Introduction}

North-central Nevada contains a large amount of gold in a variety of deposit types (Hofstra, 2002), and the origin of that gold (such as in Carlin-type deposits) is a much debated subject (Hofstra and others, 2003; Wallace and others, 2004). Major deposits occur in linear belts (fig. 1) that have long been believed to be controlled by the underlying crust and large tectonically controlled structures (Hofstra and Wallace, 2006).

Globally, the Archean Eon was the main gold mineralization period (Cameron, 1988). To help constrain the age and identity of source rocks for gold in north-central Nevada, it is important to know whether major mining districts in this region are underlain by Archean crust, known elsewhere to contain orogenic gold deposits (Hausel and Hull, 1990), or by accreted crust of the Paleoproterozoic Mojave province (Whitmeyer and Karlstrom, 2004). The Archean-Proterozoic suture zone that formed during Paleoproterozoic rifting of the continent and later Proterozoic accretion (Karlstrom and others, 2005) influenced many Phanerozoic events including patterns of sedimentation, deformation, magmatism, and hydrothermal activity (Crafford and Grauch, 2002; Grauch and others, 2003; Hofstra and Wallace, 2006). Determining the location and orientation of the Archean-Proterozoic suture zone between these provinces will help constrain the location of the Archean craton margin. 


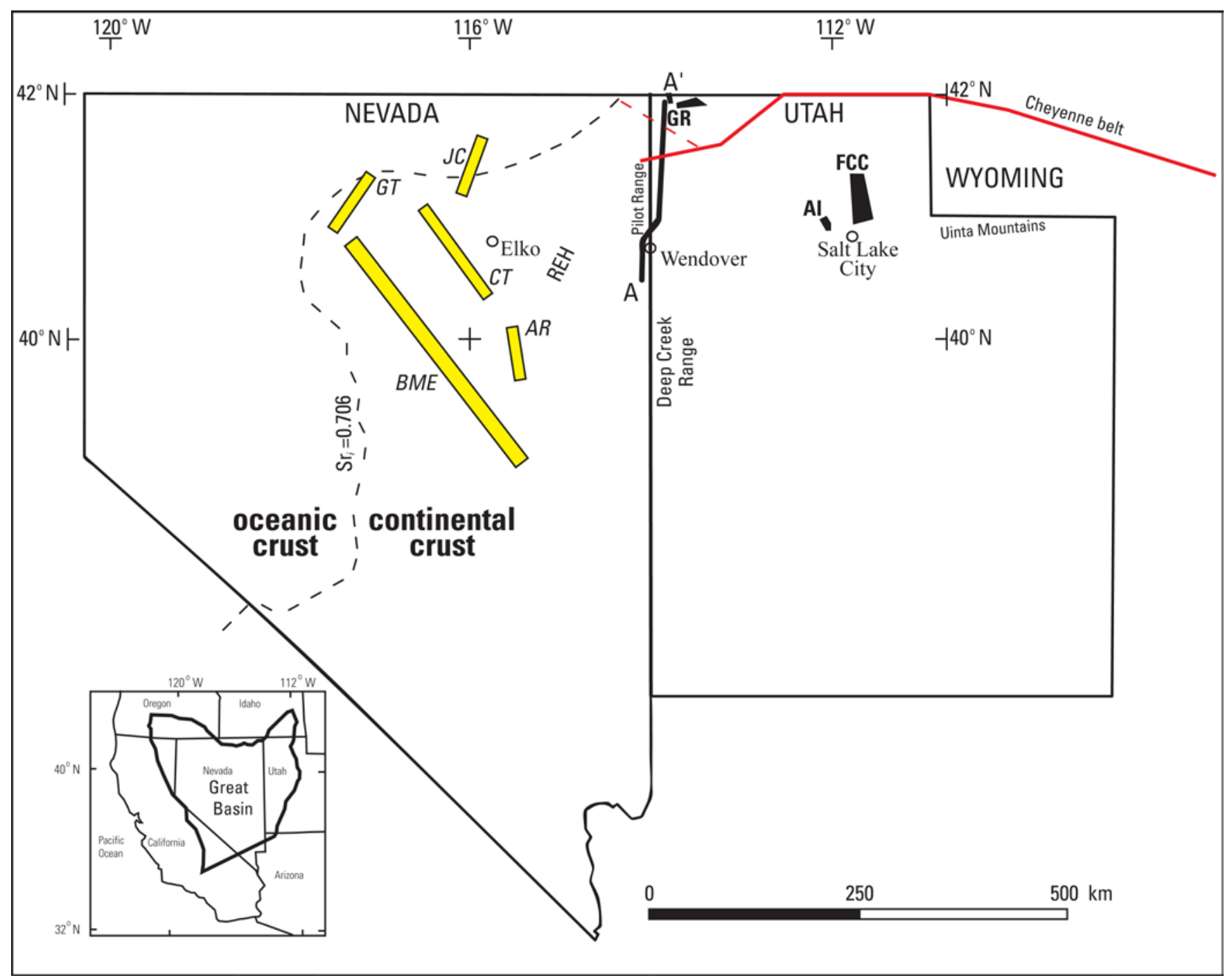

Figure 1. Location map of selected features in the Great Basin. Line $A-A^{\prime}$ is the magnetotelluric profile. Black dashed line is initial ${ }^{87} \mathrm{Sr} / 86 \mathrm{Sr}=0.706$ isopleth $\left(\mathrm{Sr}_{i}\right)$ for the inferred edge of continental crust (Kistler, 1991). Yellow rectangles are major mineral trends and lineaments. AR, Alligator Ridge district; BME, Battle Mountain-Eureka trend; CT, Carlin trend; GT, Getchell trend; JC, Jerritt Canyon district. Red solid line is leading edge of Cheyenne belt suture zone of Hart and Nelson (2008). Red dashed line is newly interpreted Cheyenne belt based on resistivity model (fig. 2). Solid black polygons are Precambrian exposures. GR, Grouse Creek/Raft River Mountains; FCC, Farmington Canyon Complex; Al, Antelope Island; REH, Ruby-East Humboldt metamorphic core complex (historically lumped with Archean exposures to the east). Inset map shows location of figure and outline of the Great Basin (heavy black line). Modified from John and others (2003). 
The nature of the crystalline basement in the Great Basin is relevant to reconstructions of Rodinia, crustal development, and ore deposit models (for example, Hofstra and Cline, 2000; Grauch and others, 2003). The suture zone (Cheyenne belt) is up to $7 \mathrm{~km}$ wide at the surface in Wyoming, with multiple zones of deformation (Houston and others, 1989) and up to $100 \mathrm{~km}$ wide at depth (Crosswhite and Humphreys, 2003). The suture zone in southern Wyoming strikes southwest in the Medicine Bow Mountains; however, west of the Medicine Bow Mountains, in the Sierra Madre, the suture trends westnorthwest. In the Great Basin, the attitude of the suture zone is unknown because it is concealed below a Neoproterozoic-Paleozoic miogeocline and Cenozoic basin fill. Hart and Nelson (2008) placed the southern limit in the northwest corner of Utah. Rodriguez and Williams (2008) placed the western limit in the northeast corner of Nevada and the southern limit along a southwest projection of the Uinta Mountains axis (Karlstrom and others, 2005; Tosdal and others, 2000). To better constrain the location and strike of the suture zone below cover, a regional north-south magnetotelluric sounding profile was acquired along the Utah-Nevada State line.

\section{Electrical Rock Properties}

Electromagnetic geophysical investigation methods detect variations in the electrical properties of rock units, in particular electrical resistivity, which is measured in units of ohm-meters $(\Omega m)$, or its inverse, electrical conductivity in units of Siemens per meter $(\mathrm{S} / \mathrm{m})$. Electrical resistivity can be correlated with geologic units on the surface and at depth using lithologic logs to provide a threedimensional picture of subsurface geology. In the upper crust, the resistivities of geologic units are largely dependent upon their fluid content, pore volume porosity, interconnected fracture porosity, and conductive mineral content (Keller, 1987).

Although there is not a one-to-one relation between lithology and resistivity, there are general correlations that can be made using typical values, even though values can be found at other geographic locations (Palacky, 1987) that may fall outside of the ranges presented below. Fluids within the pore spaces and fracture openings, especially if saline, can reduce resistivities in what would otherwise be a resistive rock matrix. Resistivity can also be lowered by the presence of electrically conductive clay minerals, graphitic carbon, and metallic mineralization. It is common, for example, for altered volcanic rocks to contain replacement minerals that have resistivities ten times lower than those of the surrounding rocks (Nelson and Anderson, 1992). Fine-grained sediments, such as clay-rich alluvium, marine shales, and other mudstones are normally conductive, with resistivities ranging from a few ohm-meters to tens of ohm-meters (Keller, 1987; Palacky, 1987). Metamorphic rocks (nongraphitic) and unaltered, unfractured igneous rocks are normally moderately to highly resistive (a few hundred to thousands of ohm-meters). Carbonate rocks can have similarly high resistivities depending on their fluid content, porosity, and impurities (Keller, 1987; Palacky, 1987). Fault zones may be moderately conductive (tens of ohm-meters) when composed of rocks fractured enough to have allowed fluid transport and consequent mineralogical alteration (Eberhart-Phillips and others, 1995) or when composed of fractured rock that has graphitic enrichment along former shear planes (Ritter and others, 2005). At greater depths, higher subsurface temperatures cause higher ionic mobility that reduces rock resistivities (Keller, 1987; Palacky, 1987). Tables of electrical resistivity for a variety of rocks, minerals, and geological environments may be found in Keller (1989) and Palacky (1987).

\section{Magnetotelluric Method}

The magnetotelluric method is a passive surface geophysical technique that uses the Earth's natural electromagnetic fields to investigate the electrical resistivity structure of the subsurface from 
depths of tens of meters to tens of kilometers (Vozoff, 1991). Natural variations of the Earth's magnetic and electric fields are measured and recorded at each magnetotelluric station. Worldwide lightning activity at frequencies of about 1 to $20,000 \mathrm{Hertz}$ and geomagnetic micropulsations at frequencies of about 0.0001 to 1 Hertz provide the majority of the signal sensed by the magnetotelluric method.

The orthogonal horizontal electric field components (Ex and Ey), magnetic field components (Hx and $\mathrm{Hy}$ ), and the vertical magnetic field component $(\mathrm{Hz})$ are recorded. For resistivity modeling, magnetotelluric data are normally rotated into directions that are parallel and perpendicular to the subsurface geologic strike. These are usually the principal directions that correspond to the direction of maximum and minimum apparent resistivity. For a two-dimensional (2-D) Earth, in which the Earth's resistivity structure varies with depth and in one lateral direction, the analysis is simplified. The magnetotelluric fields can be decoupled into transverse-electric and transverse-magnetic modes. In this case, 2-D resistivity modeling is generally computed to fit both modes. When the geology satisfies the 2-D assumption and the magnetotelluric profile is perpendicular to the geologic strike, the magnetotelluric data for the transverse-electric mode represent the electric field parallel to geologic strike, whereas the data for the transverse-magnetic mode represent the electric field across strike. The magnetotelluric method is well suited for studying complicated geological environments because the electric and magnetic field transfer functions are sensitive to vertical and horizontal variations in resistivity. The method is capable of establishing whether the electromagnetic fields are responding to subsurface rock bodies of effectively one, two, or three dimensions. An introduction to the magnetotelluric method and references for a more advanced understanding are in Kaufman and Keller (1981), Dobrin and Savit (1988), and Vozoff (1991).

\section{Magnetotelluric Survey}

Eleven magnetotelluric soundings were collected in July 2008 and September 2009 along a 151-km-long north-south profile (A-A', fig. 1) in Box Elder County, Utah, and Elko County, Nev. The profile begins south of Wendover, Nev., but north of the Deep Creek Range. It continues north of Wendover along the Nevada side of the Nevada-Utah State line, but then crosses over into Utah along the east side of the Pilot Range near latitude $41^{\circ}$. The north profile terminus is in the Grouse Creek/Raft River Mountains (GR in fig. 1) and north of the southernmost projected location of Archean exposures to the east (Egger and others, 2003; Hintze, 1980). Sounding locations were chosen to cross the suture zone (Cheyenne belt) hypothesized from interpretations of Hart and Nelson (2008). Magnetotelluric data were recorded for periods exceeding 16 to 22 hours to help characterize the lower crust. The magnetotelluric data were culled and rotated to perpendicular to the profile azimuth so that propagation modes for the signals were decoupled into transverse-electric and transverse-magnetic modes for subsequent 2-D resistivity modeling (see appendix).

Station locations were chosen for proximity to roads and in order to avoid electrical noise from powerlines. All data at the stations were collected with a portable Electromagnetic Instruments, Inc. (EMI) MT24LF system. In addition, station 37 was also collected with an MT-1 system (EMI, Inc., 1996) in 2009 after discovering the 2008 MT24LF data for station 37 were too corrupted by nearby traffic and bovine visitors. Horizontal electric fields were recorded using copper-sulfate porous pots placed in an L-shaped, three-electrode array with dipole lengths of $30 \mathrm{~m}$. The orthogonal, horizontal magnetic fields in the direction of the electric-field measurement array were sensed using highmagnetic-permeability, mu-metal-cored induction coils (EMI, Inc., 1996). Frequencies were sampled from about 0.002 to 200 Hertz using remote reference (Gamble and others, 1979) recordings of the orthogonal, horizontal components of the electric and magnetic fields and the vertical magnetic field. Table 1 lists the 11 magnetotelluric station locations. 
Table 1. Magnetotelluric station coordinates.

[Coordinates are referenced to the 1866 Clarke spheroid and North American 1927 Western United States datum. Longitude and latitude format is degrees:minutes:seconds. Universal Transverse Mercator (UTM) units and station elevations are in meters (m). UTM zone $11 \mathrm{~T}$ for stations $42-44$ and 47 . UTM zone $12 \mathrm{~T}$ for stations $37-41,45,46$, and 48 . The accuracy of the north and east component is $\pm 5 \mathrm{~m}$ and is $\pm 10 \mathrm{~m}$ for the elevation. Remote is remote reference station]

\begin{tabular}{ccccccc}
\hline Station & Remote & Longitude & Latitude & $\begin{array}{c}\text { North } \\
(\mathbf{m})\end{array}$ & $\begin{array}{c}\text { East } \\
(\mathbf{m})\end{array}$ & $\begin{array}{c}\text { Elevation } \\
(\mathbf{m})\end{array}$ \\
\hline 44 & 43 & $-114: 08: 02$ & $40: 31: 26$ & $4,489,628$ & 742,792 & 1,458 \\
43 & 44 & $-114: 07: 37$ & $40: 42: 46$ & $4,510,630$ & 742,699 & 1,371 \\
47 & 46 & $-114: 08: 08$ & $40: 49: 19$ & $4,522,735$ & 741,578 & 1,434 \\
42 & 41 & $-114: 04: 42$ & $40: 55: 40$ & $4,534,641$ & 745,997 & 1,353 \\
46 & 47 & $-113: 58: 32$ & $41: 00: 40$ & $4,544,045$ & 249,765 & 1,324 \\
41 & 42 & $-113: 57: 55$ & $41: 06: 35$ & $4,554,975$ & 251,009 & 1,300 \\
40 & 39 & $-113: 57: 39$ & $41: 15: 40$ & $4,571,771$ & 251,947 & 1,589 \\
45 & 48 & $-113: 52: 05$ & $41: 22: 21$ & $4,583,861$ & 260,136 & 1,377 \\
39 & 40 & $-113: 52: 16$ & $41: 29: 14$ & $4,596,602$ & 260,299 & 1,534 \\
48 & 45 & $-113: 51: 29$ & $41: 38: 40$ & $4,614,047$ & 261,969 & 1,627 \\
37 & none & $-113: 47: 32$ & $41: 51: 24$ & $4,637,427$ & 268,230 & 2,013 \\
\hline
\end{tabular}

\section{Resistivity Modeling}

The magnetotelluric profile soundings were initially inverted with a 2-D resistivity inversion program, RLM2DI (Mackie and others, 1997), using only the transverse-magnetic mode data because all of the observed data indicated a 3-D response (Wannamaker and others, 1984). We subsequently forward-modeled using a 2-D finite-element integral solution program, PW2DIS (Wannamaker, 1989), to improve computed fits to the 3-D magnetotelluric data recorded along the profiles. Each 2-D resistivity model is constructed by adjusting the resistivity values beneath the profile of magnetotelluric stations, so that for all stations the calculated 2-D response agrees with the measured data. Again, we primarily attempted to fit the transverse-magnetic mode data because the observed data indicated a 3-D response (fig. A1). Resistivity boundaries in the models are only approximately located because the magnetotelluric station spacing is nominally about $15 \mathrm{~km}$ along the profile. It is possible that undetected rock units may exist between stations in the resistivity model because of the wide station spacing. This is especially possible for resistive blocks in the upper kilometer of conductive crust or within the suture zone. Narrow or thin conductive zones may also be undetected.

The magnetotelluric profile projection on the resistivity model (A-A', fig. 2) passes through magnetotelluric stations 44 and 37 and bears N.12 ${ }^{\circ}$ E. (A-A', fig. 1). The finite-element grid used in the profile resistivity model consisted of $104 \times 64$ variable dimension cells extending over $5,000 \mathrm{~km}$ horizontally beyond the profile endpoints and over $1,000 \mathrm{~km}$ vertically to minimize edge effects. In the finer part of the mesh, the horizontal element size varied between $0.6 \mathrm{~km}$ and $2.9 \mathrm{~km}$, whereas the vertical element size varied between $10 \mathrm{~m}$ near the surface to $100 \mathrm{~m}$ below $500 \mathrm{~m}$ depth to $1 \mathrm{~km}$ below $5 \mathrm{~km}$ depth to $10 \mathrm{~km}$ below $40 \mathrm{~km}$ depth to over $100 \mathrm{~km}$ below $200 \mathrm{~km}$ depth. Observed data and the calculated 2-D response appear in figures A1 and A2. 


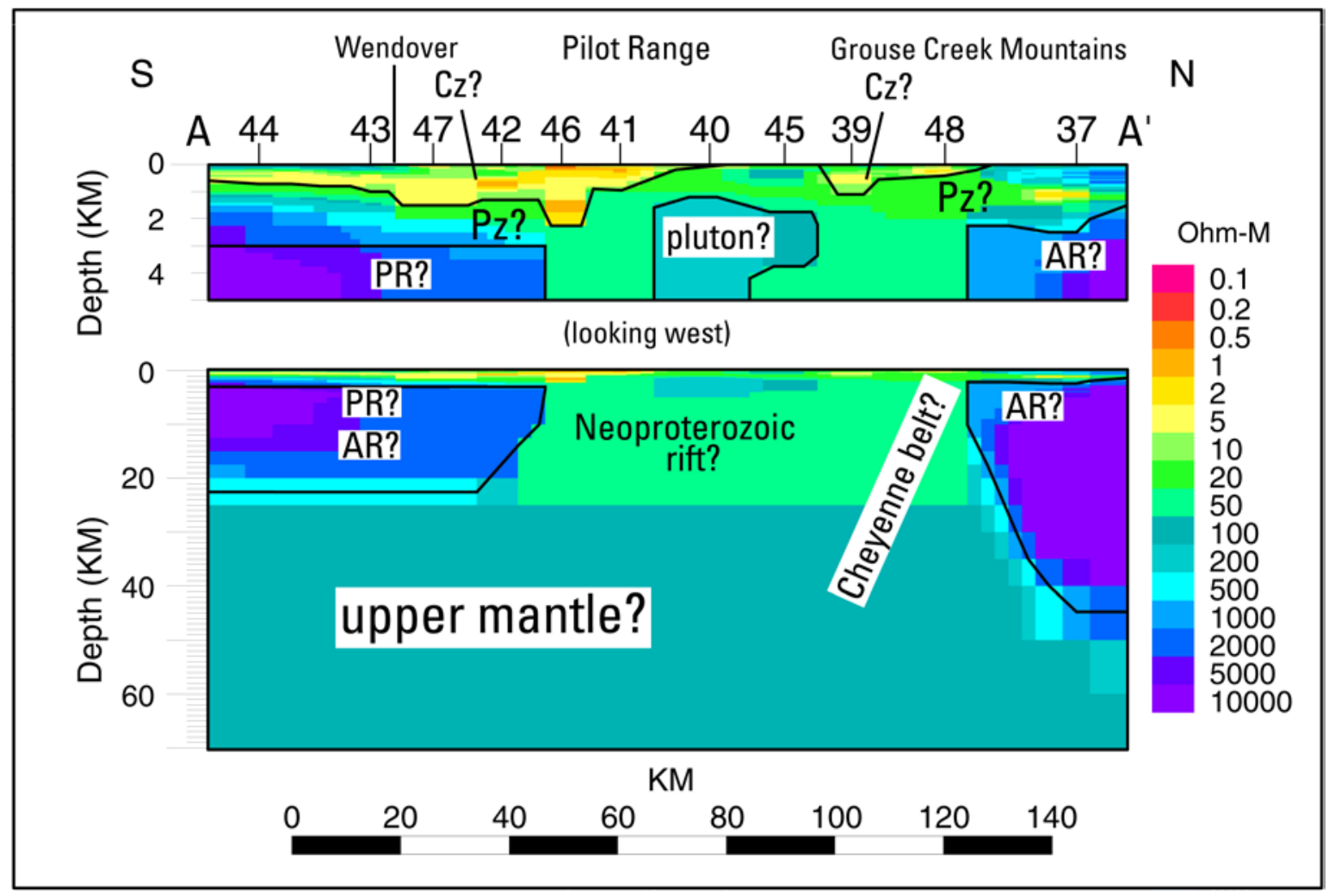

Figure 2. Two-dimensional resistivity profile model cross section. Numbered labels at top of cross section are the projected locations of magnetotelluric stations. AR, Archean; PR, Proterozoic; Pz, Paleozoic; Cz, Cenozoic. Depths are from ground surface. Physiographic descriptions are as in figure 1. No vertical exaggeration in lower cross section and 5:1 vertical exaggeration in upper cross section.

\section{Geologic Correlations}

Rodriguez and Williams $(2001,2002)$ attributed crustal high resistivity $(300$ to $1,000 \Omega \mathrm{m})$ in north-central Nevada to carbonate rock, intrusive rock, crystalline rock, or Precambrian basement, whereas Wallin and others (2008) found similar bulk average resistivities (500 to 15,000 $\Omega \mathrm{m}$ ) for these rock types from deep induction resistivity logs in southern Nevada. In north-central Nevada, moderately resistive (30 to $300 \Omega \mathrm{m}$ ) rocks were inferred to be volcanic and (or) clastic sedimentary rocks, whereas in southern Nevada, the bulk average resistivity of these types of rocks was found to range from 10 to $200 \Omega \mathrm{m}$. Broad, low resistivity ( 2 to $100 \Omega \mathrm{m})$ conductors that penetrate to lower crustal depths $(20 \mathrm{~km})$ may be interpreted as the presence of major crustal-scale suture zones (Rodriguez and others, 2007). The low resistivities can be caused by material associated with faulting or fracture filling such as mylonitic breccia, brine-filled fractures, argillaceous alteration from hydrothermal fluids, substantial graphitic carbon associated with shearing, or fluid-deposited graphite derived from organic shales in the section (Wannamaker and Doerner, 2002), or possibly some combination of these (Eberhart-Phillips and others, 1995). Shallow conductors in the upper few kilometers may be a combination of conductive (1 to $30 \Omega \mathrm{m}$ ) basin fill resting on shaley basement units, such as the Upper Devonian and Lower Mississippian Pilot Shale or Lower and Upper Mississippian Chainman Shale with similar resistivities depending on their hydrocarbon maturity (Wannamaker and Doerner, 2002). 


\section{Results}

Along the north-south magnetotelluric profile (A-A', figs. 1 and 2), the northern edge (beneath magnetotelluric station 48 ) of a broad (about $80 \mathrm{~km}$ wide) moderately conductive $(50 \Omega \mathrm{m})$ zone that penetrates to at least $20-\mathrm{km}$ depth has an electrical strike direction of N. $60^{\circ} \mathrm{W}$. (black open rectangle, fig. A6). This conductive zone appears to be a major structural boundary because its great breadth and depth suggests a very broad and thick section of conductive crust that is juxtaposed between thick (greater than $20 \mathrm{~km}$ ) resistive crust north and south of it. This major structural boundary we interpret to be a Neoproterozoic rift whose northern edge is the Cheyenne belt suture zone because its thick, broad, low resistivity suggests heavily sheared crust of rift margin proportions (about $80 \mathrm{~km}$ wide below 3-km depth).

This major anomalous conductive zone greatly contrasts with the thick section of resistive $(1,000$ to $10,000 \Omega \mathrm{m}$ ) crust (below 3-km depth), beneath magnetotelluric station 37 , that penetrates to the lower crust (about 45-km depth) suggesting that this resistive crust is intact. We interpret this resistive section of crust to be Archean because its thickness is consistent with Archean craton thickness in Wyoming based on seismic data (Keller and others, 1998), and Archean rocks are exposed in the Grouse Creek Mountains (Egger and others, 2003; Hintze, 1980).

The thick section of resistive $(1,000$ to $10,000 \Omega \mathrm{m})$ crust, south of magnetotelluric station 42 , that penetrates to the middle crust (at least 20-km depth), we interpret to be accreted Proterozoic and likely rifted Archean crust because its high resistivity, relatively smaller thickness, and its position south of the inferred suture zone along this profile (fig. 1) is consistent with accreted Proterozoic and Archean rifted crust. From the resistivity values alone, we cannot differentiate between the Proterozoic and Archean terranes, as both would appear as resistive crust, so our interpretation heavily relies upon its position south of the inferred suture zone and the tens of kilometers difference in thickness of the resistive crust north and south of the conductive suture zone.

Moderately conductive to resistive (10 to $1,000 \Omega \mathrm{m}$ ) crust in the upper $3 \mathrm{~km}$ correlate with Paleozoic rocks exposed at the surface along the profile (Hintze, 1980). The boundary between lower Paleozoic carbonates and Proterozoic metamorphic rocks is unknown because these rock types would have similar high-resistivity values. The interpreted boundary illustrated in figure 2 may be shallower or deeper. Anomalous high resistivities near stations 40 and 45 from about 1- to 5-km depth may be related to the nearby Emigrant Pass pluton (Egger and others, 2003; Hintze, 1980). Shallower conductive (0.5 to $20 \Omega \mathrm{m}$ ) rocks in the upper $0.5 \mathrm{~km}$ we infer to be Cenozoic basin fill based on Cenozoic rocks exposed at the surface (Hintze, 1980; Moore and Sorensen, 1979) and gravity basement estimates (Wallace and others, 2004).

\section{Discussion}

The structure of all surviving Archean cratons must extend to mantle depths (Mueller and Frost, 2006). Rodriguez and Williams (2008) previously reported interpreted resistivity models that supported southwest projections of the Cheyenne belt (suture zone) along the Uinta Mountains axis, but these models were based on data that were limited to the upper $20 \mathrm{~km}$ and, therefore, were not able to detect thicker (down to mantle depths) resistive crust indicative of intact Archean crust.

Previously published Cheyenne belt locations in Nevada (Foster and others, 2006; Karlstrom and others, 2005; Mueller and Frost, 2006; Tosdal and others, 2000) were drawn south of the Ruby-East Humboldt metamorphic core complex (REH, fig. 1), but the basis for those locations has since been discounted. The Ruby-East Humboldt metamorphic core complex contains rocks previously interpreted 
to be a nappe of Archean crust, but isotopic analysis by Premo and others (2008) found the rocks to be Late Cretaceous monzogranite derived from a sedimentary source dominated by Archean detritus.

The newly interpreted Cheyenne belt trace supports the revised location of Hart and Nelson (2008) and further delineates its northern edge (near station 48) to the north-central Grouse Creek Mountains (figs. 1 and 2). Its northwest strike suggests the inferred Archean terrane at magnetotelluric station 48 may be a northwest-striking extension segment subdivided by a northeast-striking transform segment where the Cheyenne belt strikes northeast (fig. 1). Intact Archean crust should appear as a thick, broad, resistive mass as seen beneath station 37 (fig. 2). The inferred Archean crust is west of the western limit of semicontinuous exposures of the Wyoming craton, but its great thickness (about $45 \mathrm{~km}$ ) suggests that it is intact beneath station 37. More magnetotelluric data north and east of station 37 would help resolve whether the inferred Archean crust is part of the intact Wyoming craton or just an accreted thick Archean block.

Isolated blocks of rifted Archean crust south of the suture zone may exist because the modeled $20-\mathrm{km}$-thick resistive crust beneath stations 44,43 , and 47 is too thick to be comprised of subhorizontal Proterozoic crust, although it is possible that the thick resistive crust is, in part, intruded by Tertiary and Cretaceous rocks south of stations 43 and 44 (Coats, 1987), or its great thickness is a result of stacked accreted blocks of subvertical Proterozoic crust. This has important implications on future mineral exploration in the area, as it suggests that future mineral exploration northeast of the gold belts in northcentral Nevada may yield additional gold deposits since these exploration targets would be closer to Archean gold sources, if ore controlling faults and stratigraphy are favorable (Cline and others, 2005; Hofstra and Wallace, 2006). Sediment-hosted mineral deposits tend to follow the same geometry of the rifted margin (Lund, 2008).

Rodriguez and others (2007) report isolated blocks of thick (10 to $20 \mathrm{~km}$ ) resistive (300 to 1,000 $\Omega \mathrm{m})$ crust beneath the Battle Mountain-Eureka, Carlin, Getchell, and Alligator Ridge mineral belts that may be isolated blocks of rifted Archean and accreted Proterozoic crust. Thus, Phanerozoic mineral deposits along these mineral belts may be produced, at least in part, from recycled Archean gold (Emsbo and others, 2006; Hofstra and Wallace, 2006, Tosdal and others, 2000).

\section{Summary and Conclusions}

The Archean-Proterozoic suture zone formed after Paleoproterozoic rifting of the continent and later Proterozoic accretion, and may have influenced subsequent patterns of sedimentation, deformation, magmatism, and hydrothermal activity. This geologic framework is the most compelling explanation of the regional north-south magnetotelluric profile resistivity model. Resistivity modeling reveals thick (greater than $20 \mathrm{~km}$ ) resistive (500 to $10,000 \Omega \mathrm{m}$ ) crust that we interpret as Archean and Proterozoic basement. A broad $(80 \mathrm{~km})$, thick (about $20 \mathrm{~km})$, moderately conductive $(50 \Omega \mathrm{m})$ zone wedged between resistive crust is consistent with a suture zone that separates thicker (about $45 \mathrm{~km}$ thick) intact Archean terrane to the north from thinner (about $20 \mathrm{~km}$ thick) rifted Archean and accreted Proterozoic terrane to the south. The interpreted suture zone supports recently suggested revisions of the Cheyenne belt north of the Uinta Mountains and north of other previously published locations. Our results suggest future mineral exploration northeast of the major gold belts in north-central Nevada may yield additional large gold deposits that follow the same geometry of the rifted margin because isolated blocks of rifted Archean crust likely exist south of the suture zone along the Utah-Nevada State line and also beneath the mineral belts in north-central Nevada. 


\section{References Cited}

Cameron, E.M., 1988, Archean gold: Relation to granulite formation and redox zoning in the crust: Geology, v. 16, p. 109-112.

Cline, J.S., Hofstra, A.H., Muntean, J.L., Tosdal, R.M., Hickey, K.A., 2005, Carlin-type gold deposits in Nevada; critical geologic characteristics and viable models, in Hedenquist, J.W., Thompson, J.F.H., Goldfarb, R.J., and Richards, J.P., eds., Economic Geology: One hundredth anniversary volume, 1905-2005: Society of Economic Geologists, p. 451-484.

Coats, R.R., 1987, Geology of Elko County, Nevada: Nevada Bureau of Mines and Geology Bulletin $101,112 \mathrm{p}$.

Crafford, A.E.J., and Grauch, V.J.S., 2002, Geologic and geophysical evidence for the influence of deep crustal structures on Paleozoic tectonics and the alignment of world-class gold deposits, north-central Nevada, USA: Ore Geology Reviews, v. 21, p. 157-184.

Crosswhite, J.A., and Humphreys, E.D., 2003, Imaging the mountainless root of the 1.8 Ga Cheyenne belt suture and clues to its tectonic stability: Geology, v. 31, no. 8, p. 669-672.

Dobrin, M.D., and Savit, C.H., 1988, Introduction to geophysical prospecting (4th ed.): New York, McGraw-Hill, 867 p.

Eberhart-Phillips, Donna, Stanley, W.D., Rodriguez, B.D., and Lutter, W.J., 1995, Surface seismic and electrical methods to detect fluids related to faulting: Journal of Geophysical Research, v. 100, no. B7, p. 12919-12936.

Egger, A.E., Dumitru, T.A., Miller, E.L., Savage, C.F.I., and Wooden, J.L., 2003, Timing and nature of Tertiary plutonism and extension in the Grouse Creek Mountains, Utah: International Geology Review, v. 45, p. 497-532.

EMI, Inc., 1996, MT-1 magnetotelluric system operation manual, version 3.2: Richmond, Calif., Electromagnetic Instruments, Inc., 220 p.

Emsbo, Poul, Groves, D.I., Hofstra, A.H., and Bierlein, F.P., 2006, The giant Carlin gold province: A protracted interplay of orogenic, basinal, and hydrothermal processes above a lithospheric boundary: Mineralium Deposita, v. 41, p. 517-525.

Foster, D.A., Mueller, P.A., Mogk, D.W., Wooden, J.L., and Vogl, J.J., 2006, Proterozoic evolution of the western margin of the Wyoming craton: Implications for the tectonic and magmatic evolution of the northern Rocky Mountains: Canadian Journal of Earth Science, v. 43, p. 1601-1619.

Gamble, T.D., Goubau, W.M., and Clarke, John, 1979, Error analysis for remote reference magnetotellurics: Geophysics, v. 44, no. 5, p. 959-968.

Grauch, V.J.S., Rodriguez, B.D., and Wooden, J.L., 2003, Geophysical and isotopic constraints on crustal structure related to mineral trends in north-central Nevada and implications for tectonic history: Economic Geology, v. 98, no. 2, p. 269-286.

Hart, Garret, and Nelson, S.T., 2008, Testing the presence of fundamental crustal boundaries in the Western United States [abs.]: Geological Society of America, Abstracts with Programs, vol. 40, no. 1, p. 87.

Hausel, W.D., and Hull, Joseph, 1990, Guide to gold mineralization and Archean geology of the South Pass Greenstone belt, Wind River Range, Wyoming, in Roberts, S., ed., Geologic field tours of western Wyoming and parts of adjacent Idaho, Montana, and Utah: Geological Survey of Wyoming, Public Information Circular, no. 29, p. 178-191.

Hintze, L.F., 1980, Geologic map of Utah: Utah Geological and Mineral Survey, Map A-1, scale $1: 500,000$.

Hofstra, A.H., 2002, Diverse origins of sedimentary rock-hosted disseminated gold deposits worldwide: Overview [abs.]: Geological Society of America, Abstracts with Programs, v. 34, no. 6, p. 140. 
Hofstra, A.H., and Cline, J.S., 2000, Characteristics and models for Carlin-type gold deposits, chap. 5 of Hagemann, S.G., and Brown, P.E., eds., Gold in 2000: Reviews in Economic Geology, v. 13, p. $163-220$.

Hofstra, A.H., and Wallace, A.R., 2006, Metallogeny of the Great Basin: Crustal evolution, fluid flow, and ore deposits: U.S. Geological Survey Open-File Report 2006-1280, 36 p.

Hofstra, A.H., John, D.A., and Theodore, T.G., 2003, A special issue devoted to gold deposits in northern Nevada: Part 2, Carlin-type deposits: Economic Geology, v. 98, no. 6, p. 1063-1268.

Houston, R.S., Duebendorfer, E.M., Karlstrom, K.E., and Premo, W.R., 1989, A review of the geology and structure of the Cheyenne belt and Proterozoic rocks of southern Wyoming, in Grambling, J.A., and Tewksbury, B.J., eds., Proterozoic geology of the southern Rocky Mountains: Geological Society of America Special Paper 235, p. 1-12

John, D.A., Hofstra, A.H., and Theodore, T.G., 2003, A special issue devoted to gold deposits in northern Nevada: Part 1, Regional studies and epithermal deposits, Preface: Economic Geology, v. 98, p. $225-234$.

Karlstrom, K.E., Whitmeyer, S.J., Dueker, Ken, Williams, M.L., Bowring, S.A., Levander, Alan, Humphreys, E.D., Keller, G.R., and the CD-ROM Working Group, 2005, Synthesis of results from the CD-ROM experiment: 4-D image of the lithosphere beneath the Rocky Mountains and implications for understanding the evolution of continental lithosphere, in Karlstrom, K.E., and Keller, G.R., eds., The Rocky Mountain region-An evolving lithosphere: Tectonics, geochemistry, and geophysics: American Geophysical Union Geophysical Monograph 154, p. 421-441.

Kaufman, A.A., and Keller, G.V., 1981, The magnetotelluric sounding method, in Methods in geochemistry and geophysics, 15: Amsterdam, Elsevier, 595 p.

Keller, G.R., Snelson, C.M., Sheehan, A.F., and Dueker, K.G., 1998, Geophysical studies of crustal structure in the Rocky Mountain region: A review: Rocky Mountain Geology, v. 33, no. 2, p. 217-228.

Keller, G.V., 1987, Rock and mineral properties, in Nabighian, M.N., ed., Electromagnetic methods in applied geophysics theory: Tulsa, Okla., Society of Exploration Geophysicists, v. 1, p. 13-51.

Keller, G.V., 1989, Electrical properties, in Carmichael, R.S., ed., Practical handbook of physical properties of rocks and minerals: Boca Raton, Fla., CRC Press, p. 359-427.

Kistler, R.W., 1991, Chemical and isotopic characteristics of plutons in the Great Basin, in Raines, G.L., Lisle, R.E., Schafer, R.W., and Wilkinson, W.H., eds., Geology and ore deposits of the Great Basin: Geological Society of Nevada Symposium, Reno, 1991, Proceedings, p. 107-109.

Lund, Karen, 2008, Geometry of the Neoproterozoic and Paleozoic rift margin of western Laurentia: Implications for mineral deposit settings: Geosphere, v. 4, no. 2, p. 429-444.

Mackie, R.L., Rieven, Shirley, and Rodi, William, 1997, User's manual and software documentation for two-dimensional inversion of magnetotelluric data: Cambridge, Mass., Massachusetts Institute of Technology, Earth Resources Laboratory, 10 p.

Moore, W.J., and Sorensen, M.L., 1979, Geologic map of the Tooele $1^{\circ}$ by $2^{\circ}$ quadrangle, Utah: U.S. Geological Survey Miscellaneous Investigation Series Map I-1132, 1:250,000 scale.

Mueller, P.A., and Frost, C.D., 2006, The Wyoming province: A distinctive Archean craton in Laurentian North America: Canadian Journal of Earth Science, v. 43, p. 1391-1397.

Nelson, P.H., and Anderson, L.A., 1992, Physical properties of ash flow tuff from Yucca Mountain, Nevada: Journal of Geophysical Research, v. 97, no. B5, p. 6823-6841.

Palacky, G.J., 1987, Resistivity characteristics of geologic targets, in Nabighian, M.N., ed., Electromagnetic methods in applied geophysics: Tulsa, Okla., Society of Exploration Geophysicists, v. 1, p. 53-129. 
Premo, W.R., Castiñeiras, Pedro, and Wooden, J.L., 2008, SHRIMP-RG U-Pb isotopic systematics of zircon from the Angel Lake orthogneiss, East Humboldt Range, Nevada: Is this really Archean crust?: Geosphere, v. 4, p. 963-975.

Reddy, I.K., Rankin, David, and Phillips, R.J., 1977, Three-dimensional modeling in magnetotelluric and magnetic variational sounding: Geophysics Journal of the Royal Astronomical Society, v. 51, p. 313-325.

Ritter, Oliver, Hoffmann-Rothe, Arne, Bedrosian, P.A., Weckmann, Ute, and Haak, Volker, 2005, Electrical conductivity images of active and fossil fault zones, in Bruhn, D., and Burlini, L., eds., High-strain zones; structure and physical properties: Geological Society Special Publications, v. 245, p. 165-186.

Rodriguez, B.D., and Williams, J.M., 2001, Deep regional resistivity structure across the Battle Mountain-Eureka and Carlin trends, north-central Nevada: U.S. Geological Survey Open-File Report 01-346, 165 p.

Rodriguez, B.D., and Williams J.M., 2002, Resistivity structure across the Humboldt River Basin, north-central Nevada: U.S. Geological Survey, Open-File Report 02-39, 114 p.

Rodriguez, B.D., and Williams J.M., 2008, Tracking the Archean-Proterozoic suture zone in the northeastern Great Basin, Nevada and Utah: Geosphere, v. 4, no. 2, p. 315-328.

Rodriguez, B.D., Sampson, J.A., and Williams, J.M., 2007, Major crustal fault zone trends and their relation to mineral belts in the north-central Great Basin, Nevada: U.S. Geological Survey, Open-File Report 2007-1115, 17 p.

Tosdal, R.M., Wooden, J.L, and Kistler, R.W., 2000, Geometry of the Neoproterozoic continental break-up, and implications for location of Nevadan mineral belts, in Cluer, J.K., Price, J.G., Struhsacker, R.F., Hardyman, R.F., and Morris, C.L., eds., Geology and ore deposits 2000: The Great Basin and beyond: Geological Society of Nevada, Reno, Nev., Symposium Proceedings, v. 1, p. 451-466.

Vozoff, Keeva, 1972, The magnetotelluric method in the exploration of sedimentary basins: Geophysics, v. 37, p. 980-141.

Vozoff, Keeva, 1991, The magnetotelluric method, in Nabighian, M.N., ed., Electromagnetic methods in applied geophysics: Tulsa, Okla., Society of Exploration Geophysicists, v. 2, pt. B, p. 641-711.

Wallace, A.R., Ludington, Steve, Mihalsky, M.J., Peters, S.G., Theodore, T.G., Ponce, D.A., John, D.A., and Berger, B.R., 2004, Assessment of metallic mineral resources in the Humboldt River basin, northern Nevada: U.S. Geological Survey Bulletin 2218, 295 p.

Wallin, E.L., Rodriguez, B.D., and Williams, J.M., 2008, Deep resistivity structure of Mid Valley, Nevada Test Site, Nevada: U.S. Geological Survey Open-File Report 2008-1118, 50 p.

Wannamaker, P.E., 1989, PW2DIS user documentation-Finite element program for solution of magnetotelluric responses and sensitivities for two-dimensional Earth resistivity structure: Earth Science Laboratory, University of Utah Research Institute, Salt Lake City, Utah, ESL-89043-TR, $50 \mathrm{p}$.

Wannamaker, P.E. and Doerner, W.M., 2002, Crustal structure of the Ruby Mountains and southern Carlin trend region, Nevada, from magnetotelluric data: Ore Geology Reviews, v. 21, p. 185-210. Wannamaker, P.E., Hohmann, G.W., and Ward, S.H., 1984, Magnetotelluric responses of threedimensional bodies in layered earths: Geophysics, v. 49, no. 9, p. 1517-1533.

Whitmeyer, S.J., and Karlstrom, K.E., 2004, Progressive Proterozoic growth of southern Laurentia by magmatic stabilization of lithosphere [abs.]: Geological Society of America, Abstracts with Programs, v. 36 , no. 5 , p. 404 . 


\section{Appendix 1. Magnetotelluric Data}

The recorded time-series data were converted to the frequency domain and processed to determine the impedance tensor, which is used to derive apparent resistivities and phases at each site. Rotation of the impedance tensor allows for decoupling into the transverse-electric and transversemagnetic modes. The data provided here were rotated to a fixed angle perpendicular to the given nominal profile orientation. Cross-power files were sorted to select optimal signal-to-noise time-series datasets.

Cultural features, such as fences, pipelines, communication lines, moving vehicles and trains, and other manmade sources of electromagnetic noise, can contaminate the responses of the magnetotelluric system.

The figures in appendix 1 represent the field-processed magnetotelluric data for each station, after the time-series data were converted to the frequency domain and the tensor-transfer function was developed. The data at each station include some data scatter and poor signal-to-noise ratios. Efforts aimed at removing noisy data points were to visually inspect and digitally select the best signal-to-noise field data to combine and remote reference processing.

Six data diagram types are given:

1. Apparent resistivity (fig. A1)

2. Impedance phase (fig. A2)

3. Impedance skew (fig. A3)

4. Multiple coherency (fig. A4)

5. Impedance polar plots (fig. A5)

6. Tipper strike (fig. A6)

Apparent resistivity (fig. A1) is the ratio at a given frequency of the electric field strength magnitude to the magnetic field strength magnitude. The impedance phase (fig. A2) is proportional to the slope of the apparent resistivity curve on a log-log plot, relative to a baseline at $-45^{\circ}$ (Vozoff, 1991). A measure of the dimensionality for magnetotelluric data is provided by the impedance skew (fig. A3) of the impedance tensor (Vozoff, 1972). If the effective, measured resistivity response to the geology beneath an magnetotelluric station is truly one or two dimensional, then the skew will be zero. Both instrumental and environmental sources of noise contribute to nonzero skew values but are typically small (about 0.1) for relatively low noise-level recordings. Higher skews (more than 0.2) indicate either the resistivity response to 3-D geology or higher levels of noise.

In the study area, noise from a number of small powerlines and small moving vehicles was negligible at distances of $0.25 \mathrm{~km}$ and farther from the noise source. Powerline amplitude levels were measured at each site and were typically less than 20 percent of the maximum recordable signals. Noise from larger power lines, power generators, pipelines, and trains was negligible at distances greater than $5 \mathrm{~km}$. Local lightning, wind, and rainstorms also can degrade data quality, but these noise sources were avoided by not recording during active thunderstorm periods. Burying the magnetic induction coils and keeping the electric dipole wires flat on the ground helped to minimize wind noise.

Predicted values of the electric field can be computed from the measured values of the magnetic field (Vozoff, 1991). The coherence of the predicted electric field with the measured electric field is a measure of the signal-to-noise ratio provided in the multiple coherency plots (fig. A4). Values are normalized between 0 and 1 , where values at 0.5 signify signal levels equal to noise levels. For this 
dataset, coherencies generally were at an acceptable level, except at times in the frequency "dead band" (0.01 to 5 Hertz) (Dobrin and Savit, 1988) and also at times at frequencies below 0.01 Hertz.

The impedance polar plots (fig. A5) provide a measure of the magnetotelluric data dimensionality (Reddy and others, 1977). For 1-D resistivity structures, the principal impedance (off diagonal elements) polar diagram (dashed line) is a circle. For 2-D or 3-D resistivity structures, the principal impedance polar diagram (dashed line) elongates either parallel to or perpendicular to strike direction. Over resistors, the principal impedance polar diagram elongates perpendicular to strike direction, whereas over conductors, the principal impedance polar diagram elongates parallel to strike direction. For 2-D resistivity structures, the additional impedance polar diagram (solid line) attains the shape of a symmetric clover leaf. For 3-D resistivity structures, the additional impedance polar diagram (solid line) elongates in one direction, and its amplitude is comparable to that of the principal impedance polar diagram (dashed line), although high noise levels can produce the same effect on the polar diagram. A 3-D analysis of polar plots at each frequency should also take into account the corresponding coherence and skew values along with their associated error levels. The polar plots computed for our data show the electromagnetic response for all stations was 3-D over all frequencies measured.

The tipper can be calculated from the vertical component of the magnetic field. The tipper strike (fig. A6) typically is used to help resolve the $90^{\circ}$ ambiguity in the impedance rotation angle. 

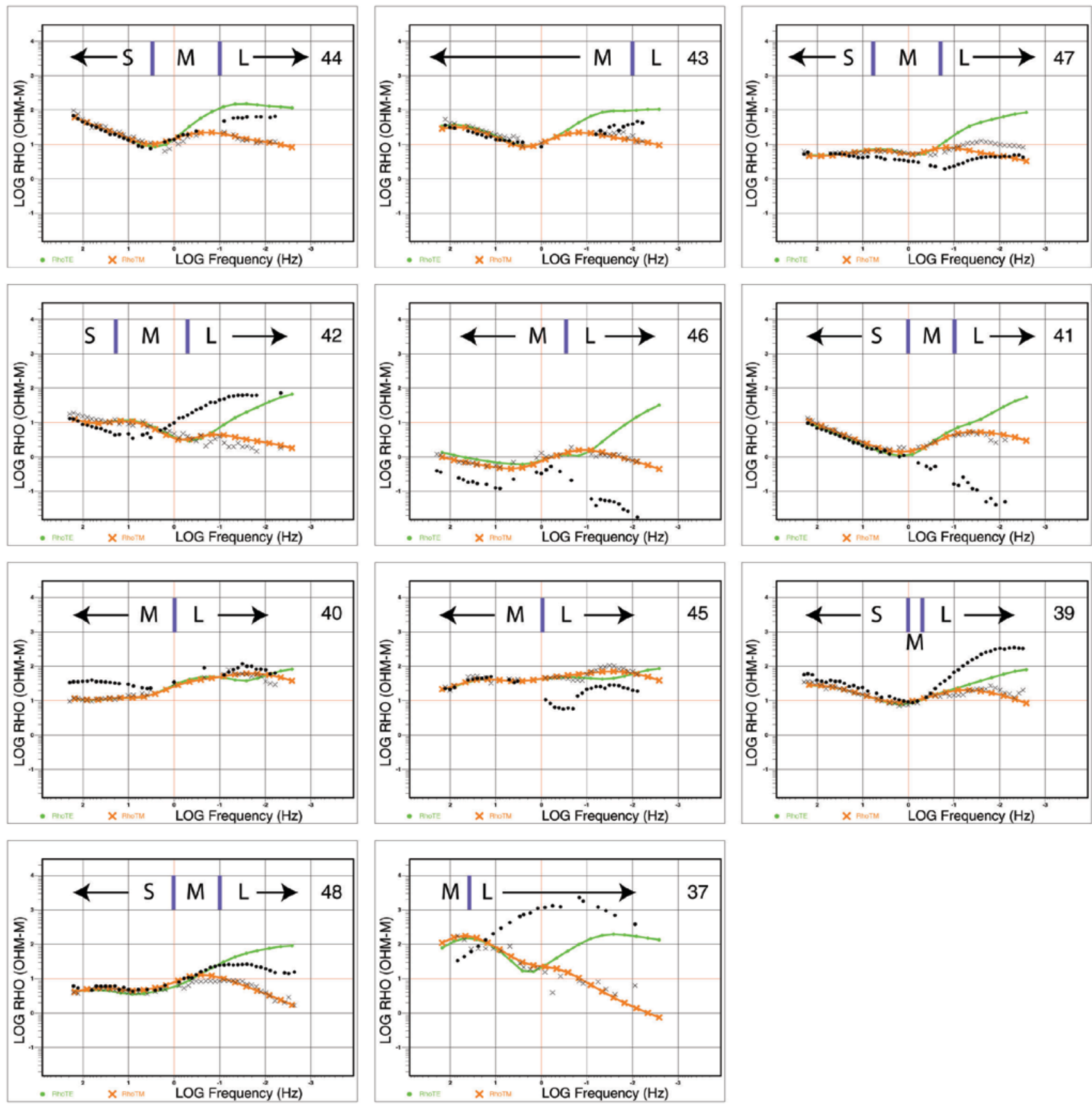

Figure A1. Observed and calculated resistivity data for profile A-A' (fig. 2). Black circles and crosses are transverse-electric and transverse-magnetic mode observed data. Green circles and orange crosses are transverse-electric and transverse-magnetic mode calculated two-dimensional resistivity response. 3-D label indicates three-dimensional character of electromagnetic response ( $\mathrm{S}$ for small, $\mathrm{M}$ for medium, or $\mathrm{L}$ for large 3-D response). 

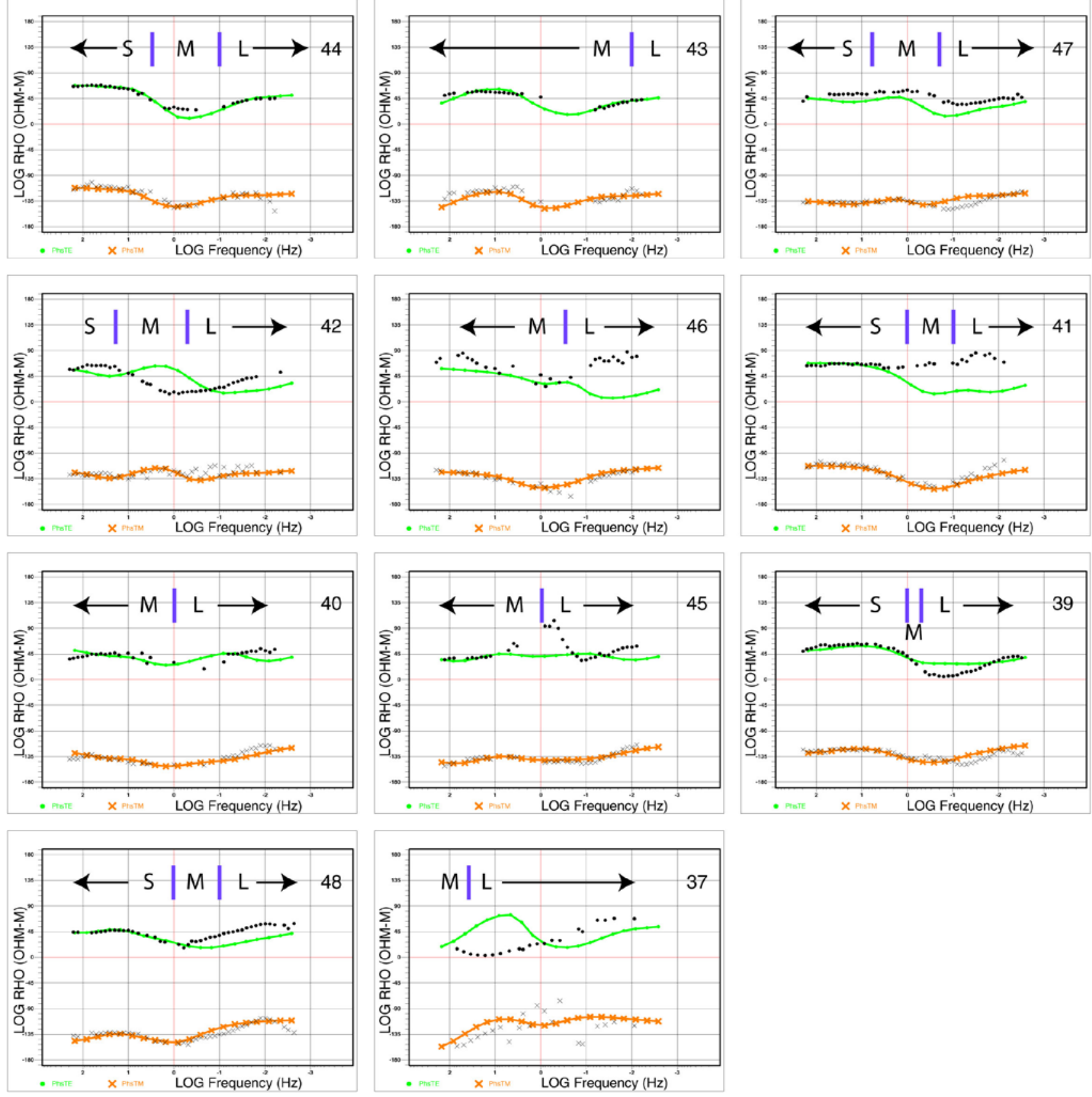

Figure A2. Observed and calculated phase data for profile A-A' (fig. 2). Black circles and crosses are transverse-electric and transverse-magnetic mode observed data. Green circles and orange crosses are transverse-electric and transverse-magnetic mode calculated two-dimensional resistivity response. 3-D label indicates three-dimensional character of electromagnetic response ( $\mathrm{S}$ for small, $\mathrm{M}$ for medium, or $\mathrm{L}$ for large 3-D response). 


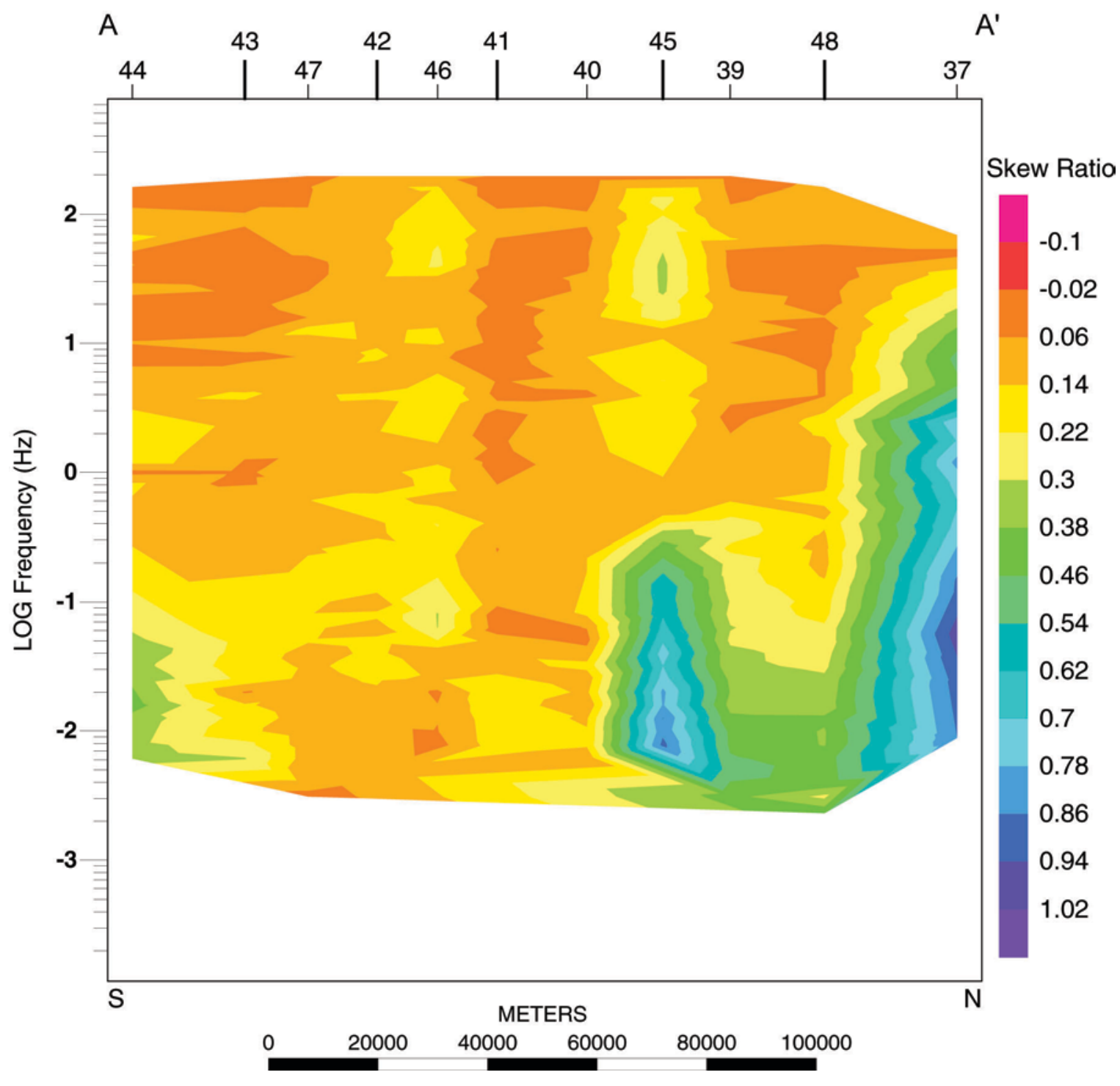

Figure A3. Impedance skew ratio for profile A-A' (fig. 2). Numbered labels at figure top are magnetotelluric stations. 


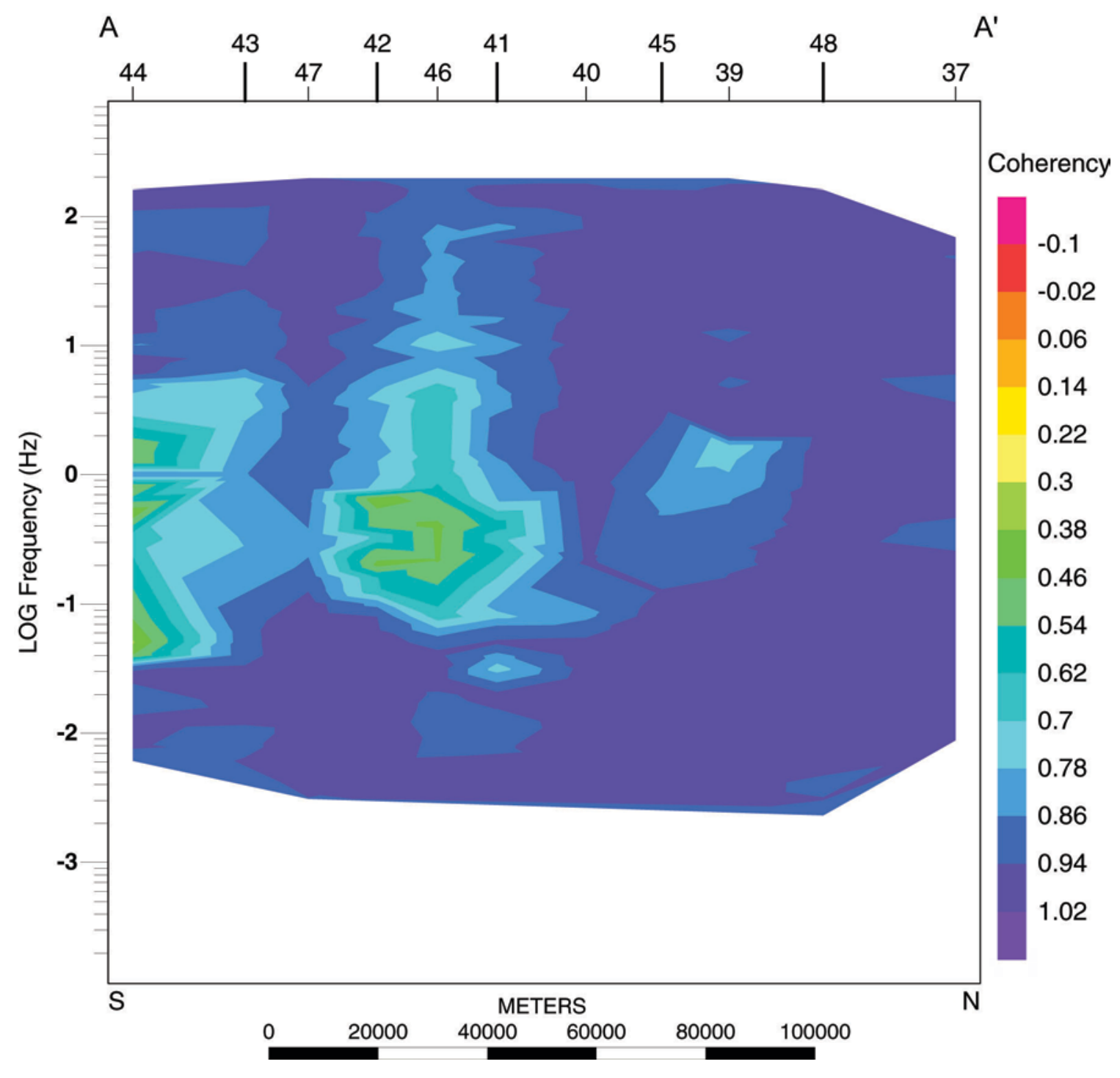

Figure A4A. Multiple coherency for profile A-A' (fig. 2). Coherency of the predicted Ex electric field with the measured Ex electric field. Numbered labels at figure top are magnetotelluric stations. 


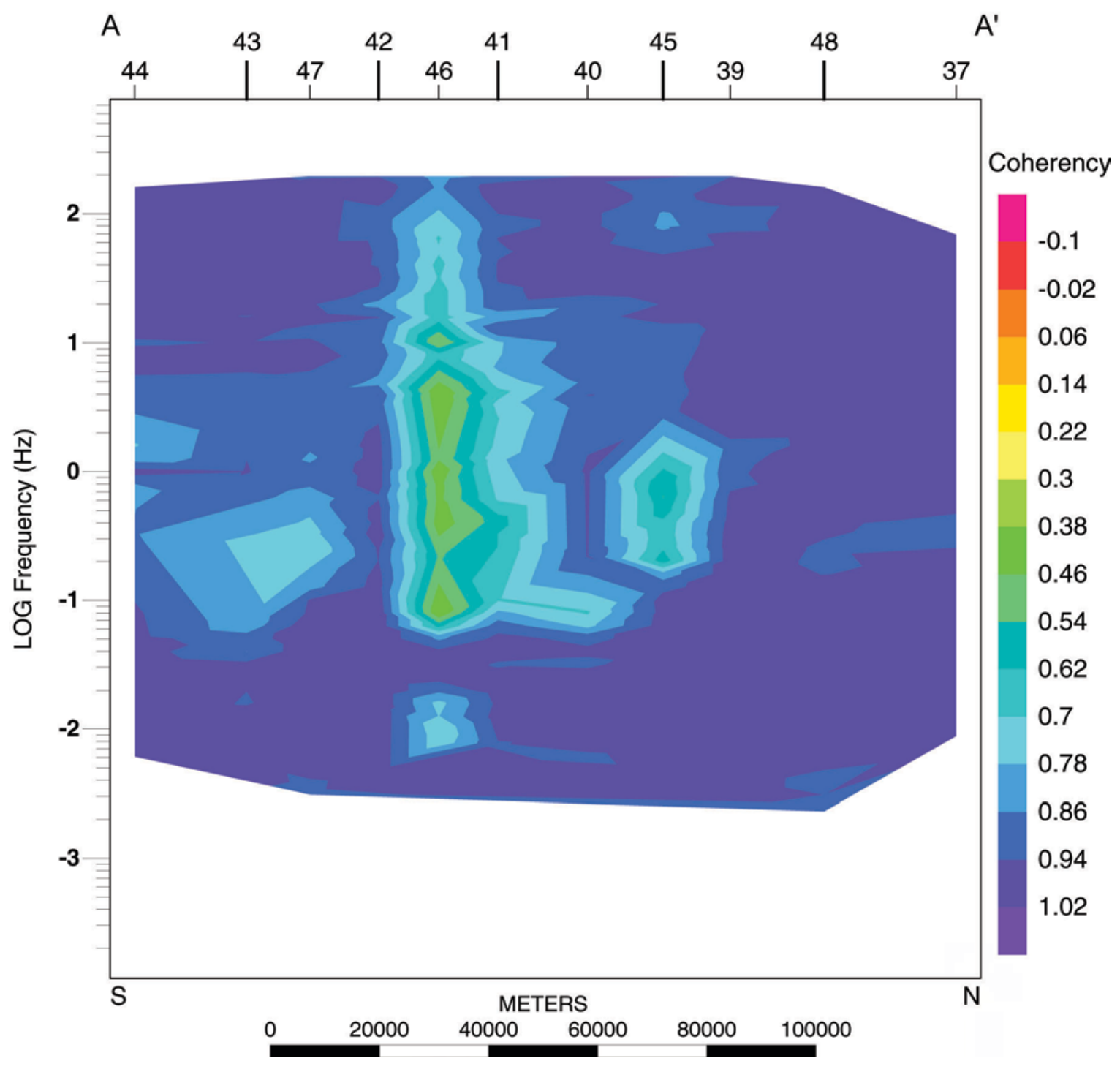

Figure A4B. Multiple coherency for profile A-A' (fig. 2). Coherency of the predicted Ey electric field with the measured Ey electric field. Numbered labels at figure top are magnetotelluric stations. 


\section{Station 44}

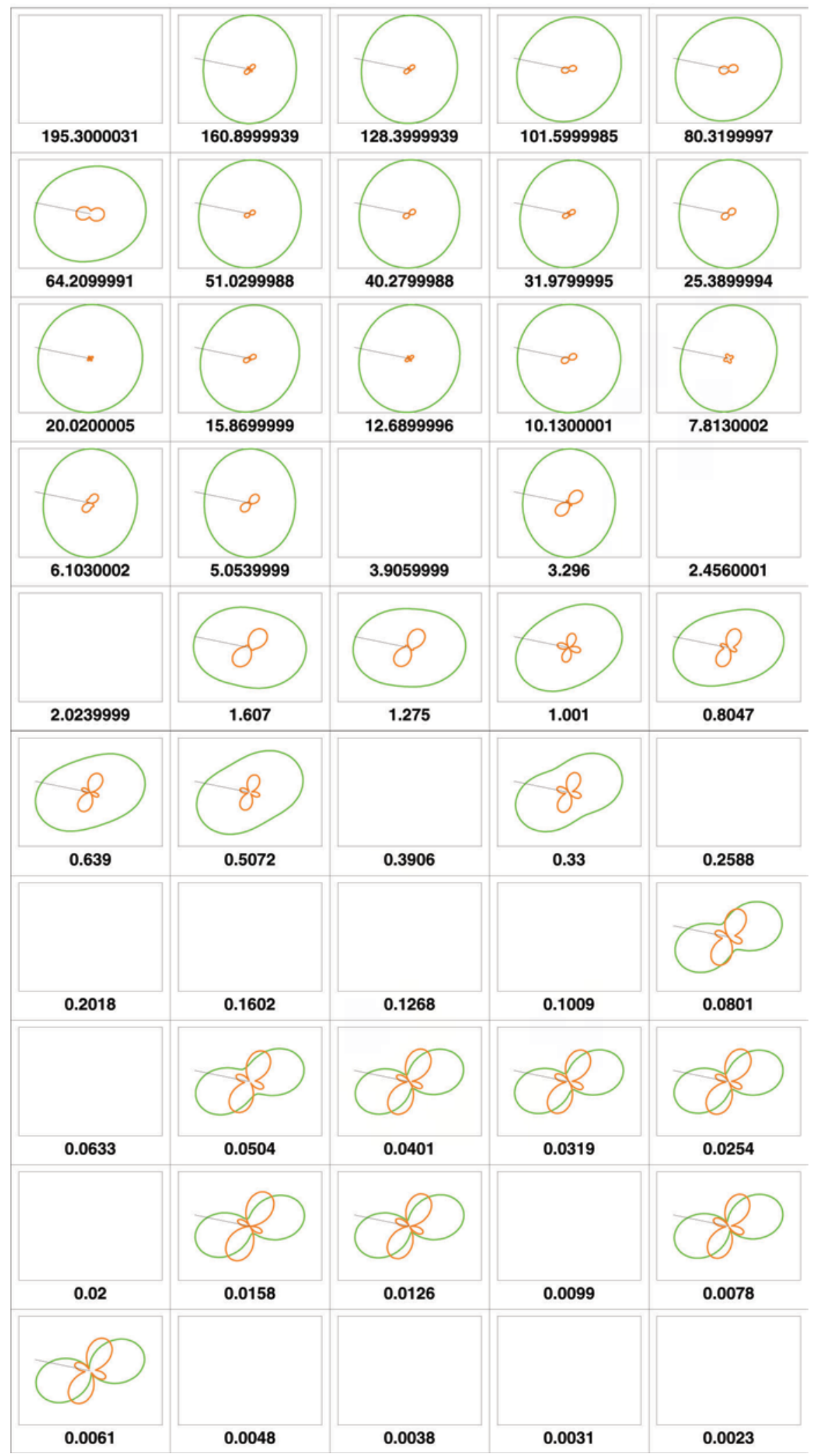

Figure A5A. Impedance polar plots for magnetotelluric station 44 (fig. 2). North $\left(0^{\circ}\right)$ is up. Green line is Zxy. Orange line is Zxx. Straight black line is rotation angle $\left(-78^{\circ}\right)$. Numbered label at each diagram bottom is frequency in Hertz. 


\section{Station $\mathbf{4 3}$}

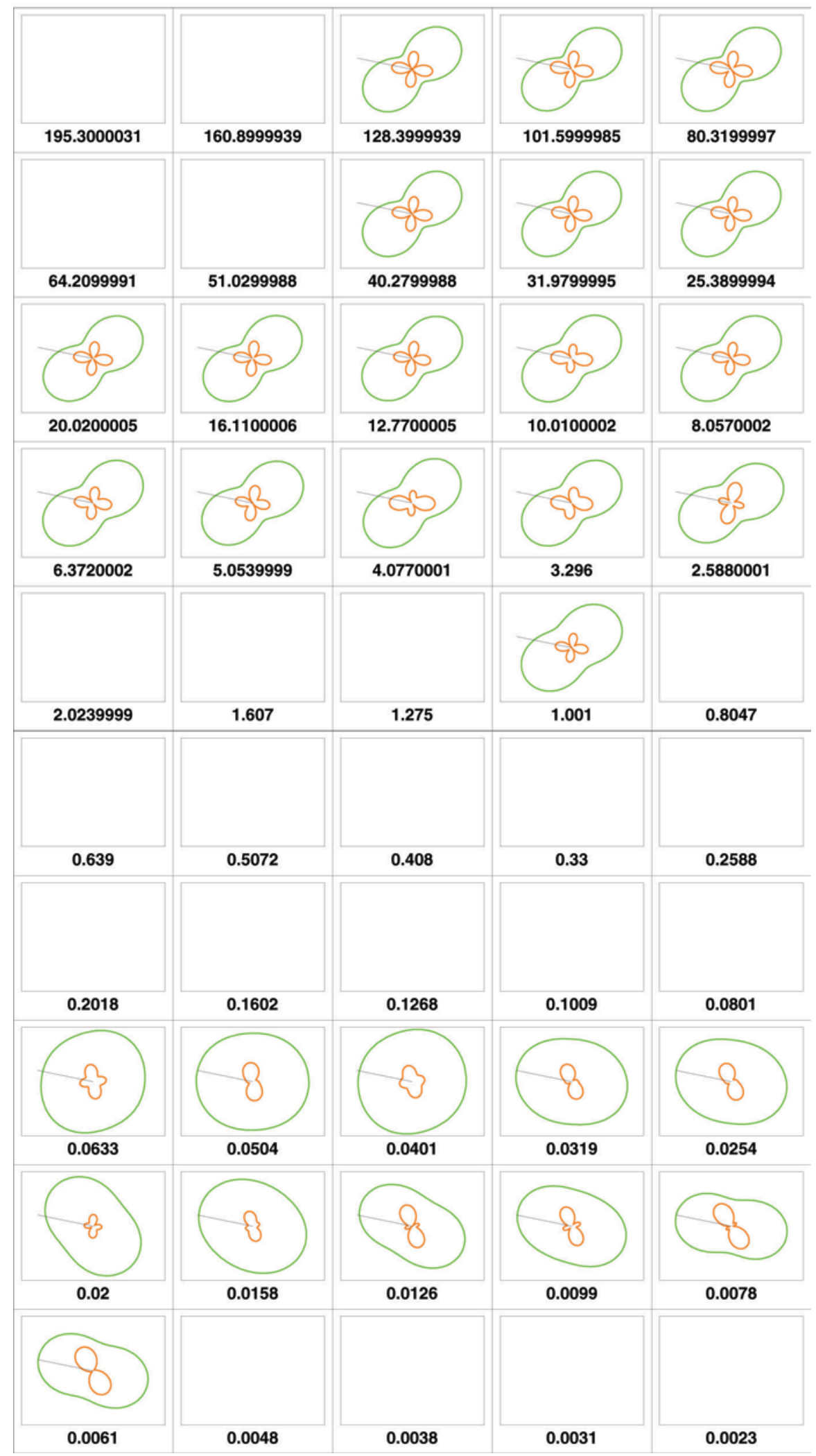

Figure A5B. Impedance polar plots for magnetotelluric station 43 (fig. 2). North $\left(0^{\circ}\right)$ is up. Green line is Zxy. Orange line is Zxx. Straight black line is rotation angle $\left(-78^{\circ}\right)$. Numbered label at each diagram bottom is frequency in Hertz. 


\section{Station 47}

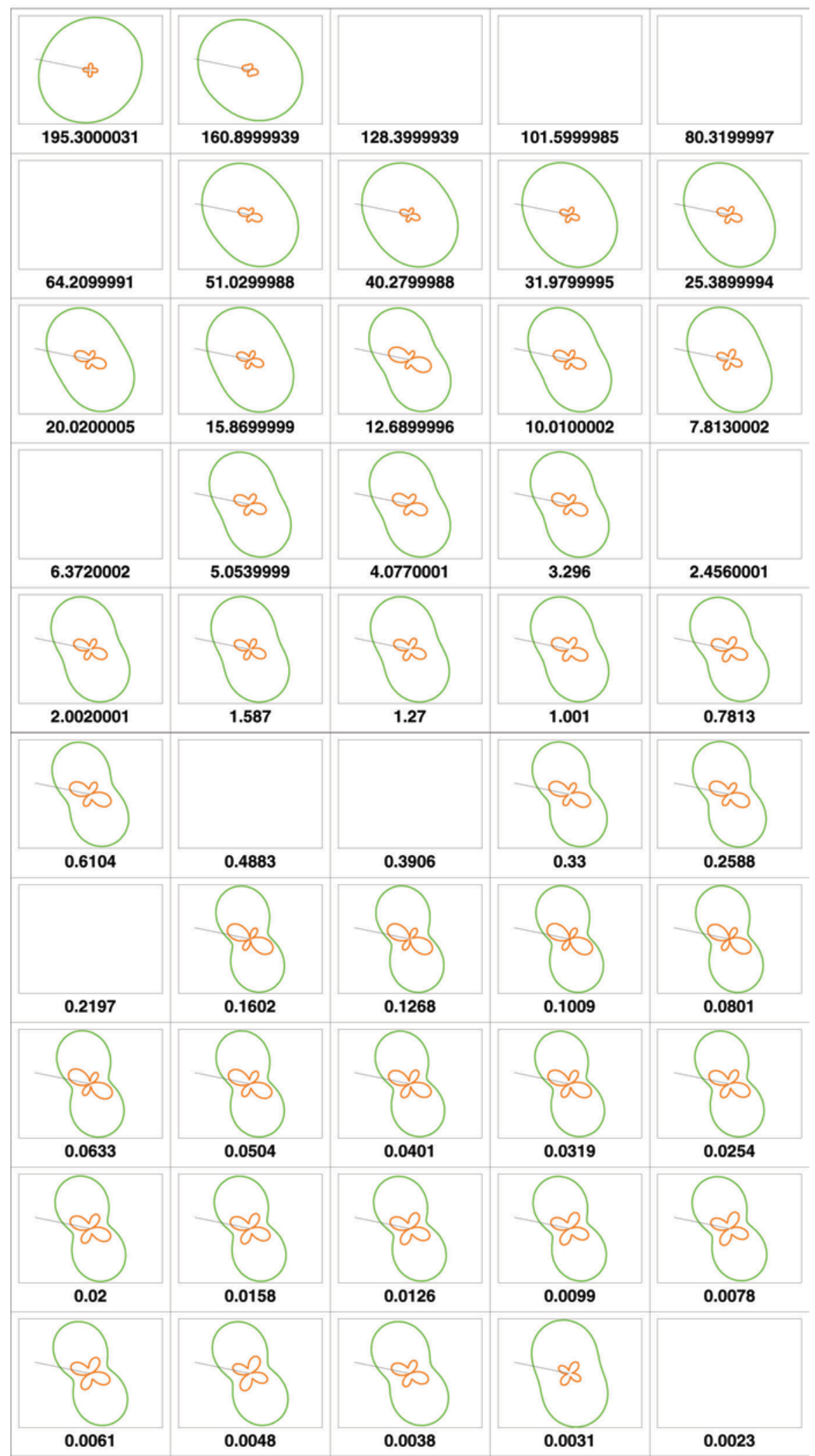

Figure A5C. Impedance polar plots for magnetotelluric station 47 (fig. 2). North $\left(0^{\circ}\right)$ is up. Green line is Zxy. Orange line is Zxx. Straight black line is rotation angle $\left(-78^{\circ}\right)$. Numbered label at each diagram bottom is frequency in Hertz. 


\section{Station 42}

\begin{tabular}{|c|c|c|c|c|}
\hline 195.3000031 & 160.89999939 & 128.3999939 & 101.5999985 & 80.3199997 \\
\hline 64.2099991 & 51.0299988 & 40.2799988 & 31.9799995 & 25.3899994 \\
\hline 20.0200005 & 15.8699999 & 12.7700005 & 10.0100002 & 8.0570002 \\
\hline 6.1030002 & 4.8829999 & 3.9059999 & 3.296 & 2.4549999 \\
\hline 2.0020001 & 1.587 & 1.27 & 1.001 & 0.7813 \\
\hline 0.639 & 0.507 & 0.4078 & 0.33 & 0.2586 \\
\hline 0.2014 & 0.1598 & 0.1266 & 0.1007 & 0.0797 \\
\hline 0.0629 & 0.05 & 0.0397 & 0.0317 & 0.0252 \\
\hline 0.0198 & 0.0156 & 0.0122 & 0.0095 & 0.0076 \\
\hline 0.0061 & 0.0046 & 0.0031 & NULL & NULL \\
\hline
\end{tabular}

Figure A5D. Impedance polar plots for magnetotelluric station 42 (fig. 2). North $\left(0^{\circ}\right)$ is up. Green line is Zxy. Orange line is Zxx. Straight black line is rotation angle $\left(-78^{\circ}\right)$. Numbered label at each diagram bottom is frequency in Hertz. 


\section{Station 46}

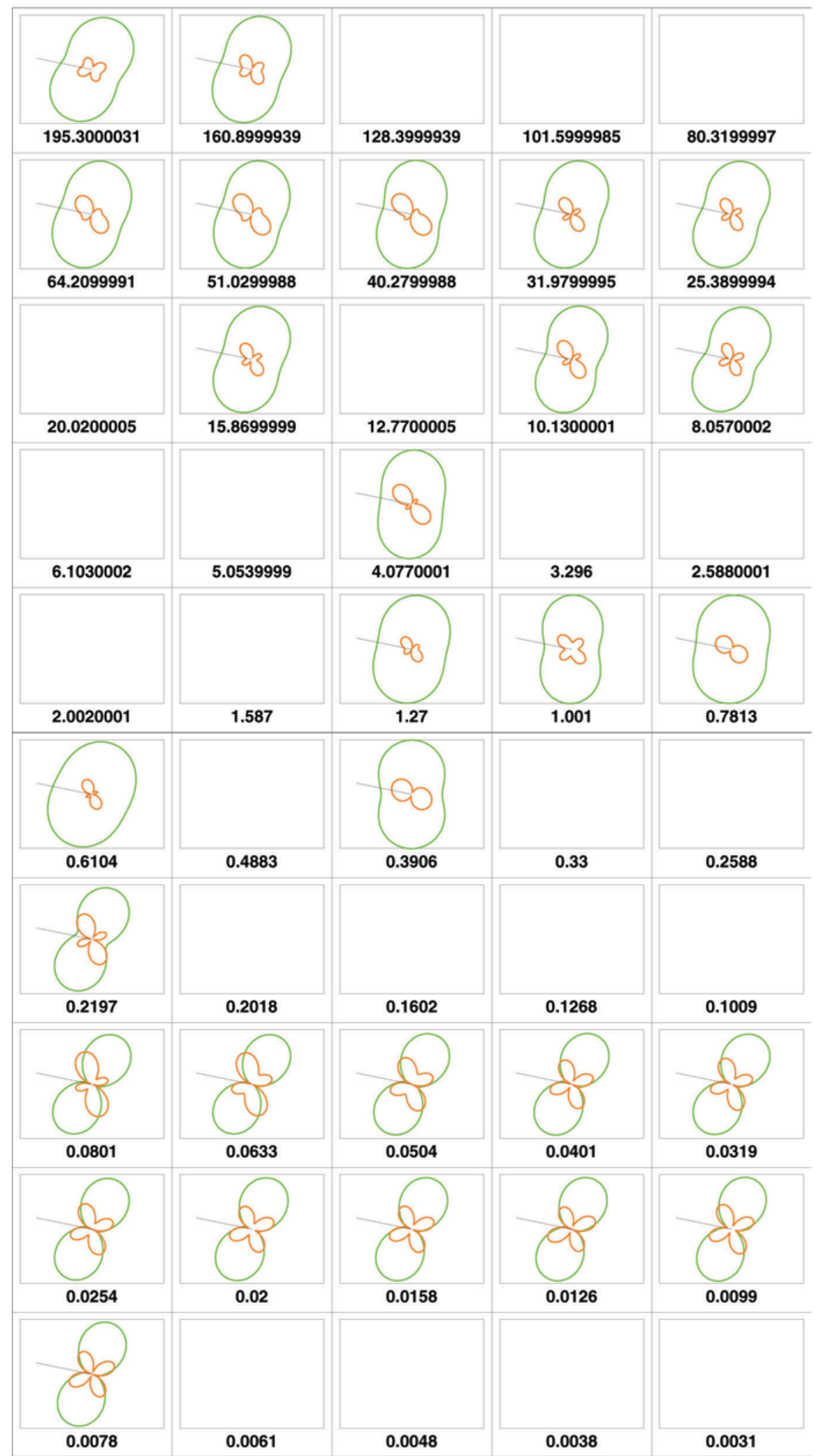

Figure A5E. Impedance polar plots for magnetotelluric station 46 (fig. 2). North $\left(0^{\circ}\right)$ is up. Green line is Zxy. Orange line is Zxx. Straight black line is rotation angle $\left(-78^{\circ}\right)$. Numbered label at each diagram bottom is frequency in Hertz. 


\section{Station 41}

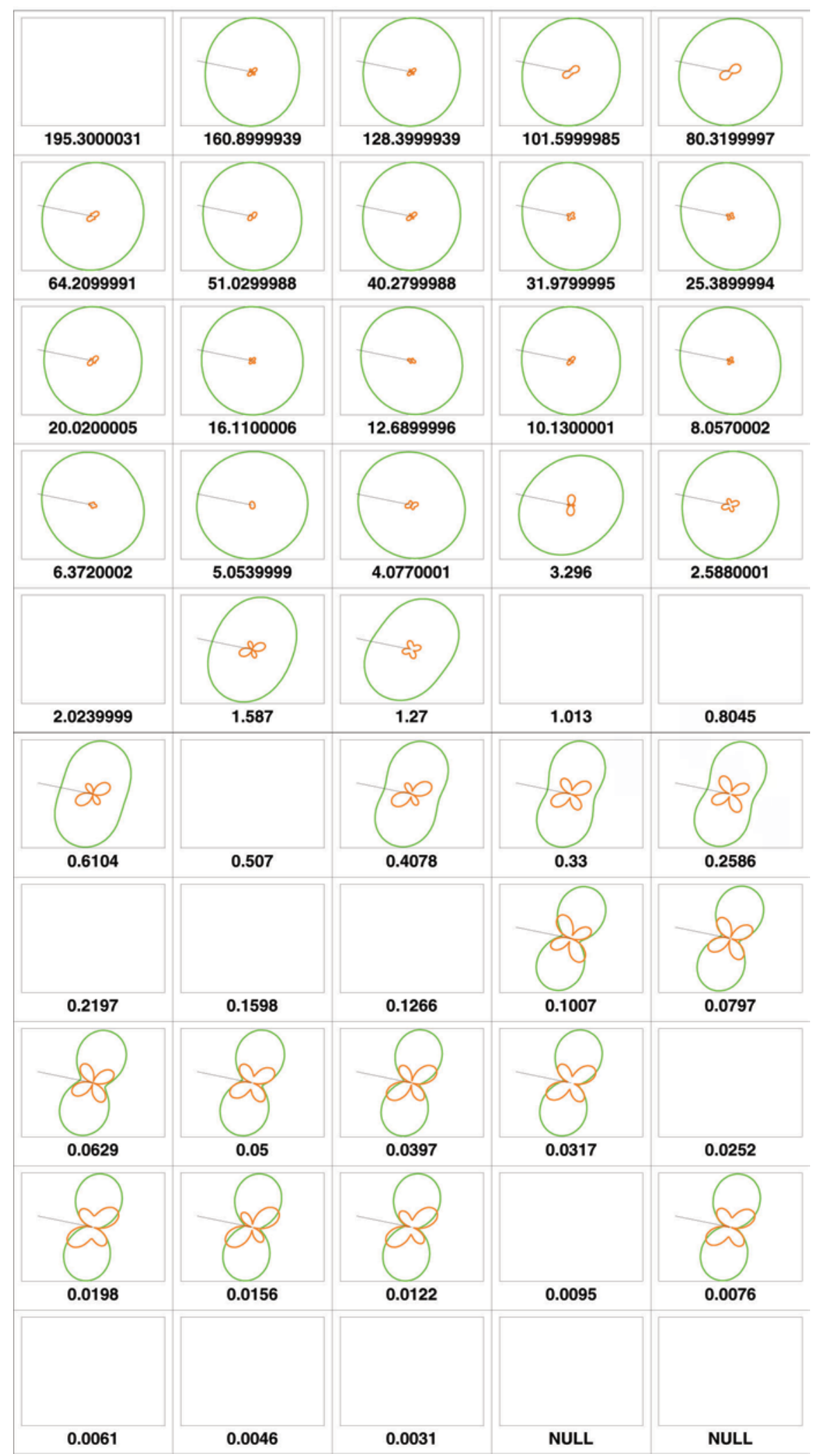

Figure A5F. Impedance polar plots for magnetotelluric station 41 (fig. 2). North $\left(0^{\circ}\right)$ is up. Green line is Zxy. Orange line is Zxx. Straight black line is rotation angle $\left(-78^{\circ}\right)$. Numbered label at each diagram bottom is frequency in Hertz. 


\section{Station $\mathbf{4 0}$}

\begin{tabular}{|c|c|c|c|c|}
\hline 195.3000031 & 160.8999939 & 128.3999939 & 101.5999985 & 80.3199997 \\
\hline 64.2099991 & 51.0299988 & 40.2799988 & 31.9799995 & 25.3899994 \\
\hline 20.0200005 & 16.1100006 & 12.7700005 & 10.1300001 & 7.8130002 \\
\hline 6.3720002 & 5.0539999 & 3.9059999 & 3.296 & 2.4560001 \\
\hline 2.0239999 & 1.607 & 1.275 & 1.001 & 0.8047 \\
\hline 0.639 & 0.5072 & 0.408 & 0.33 & 0.2588 \\
\hline 0.2197 & 0.2018 & 0.1602 & 0.1268 & 0.1009 \\
\hline 0.0801 & 0.0633 & 0.0504 & 0.0401 & 0.0319 \\
\hline 0.0254 & 0.02 & 0.0158 & 0.0126 & 0.0099 \\
\hline 0.0078 & 0.0061 & 0.0048 & 0.0038 & 0.0031 \\
\hline
\end{tabular}

Figure A5G. Impedance polar plots for magnetotelluric station 40 (fig. 2). North $\left(0^{\circ}\right)$ is up. Green line is Zxy. Orange line is Zxx. Straight black line is rotation angle $\left(-78^{\circ}\right)$. Numbered label at each diagram bottom is frequency in Hertz. 


\section{Station $\mathbf{4 5}$}

\begin{tabular}{|c|c|c|c|c|}
\hline 195.3000031 & 160.8999939 & 128.3999939 & 101.5999985 & 80.3199997 \\
\hline 64.2099991 & 51.0299988 & 40.2799988 & 31.9799995 & 25.3899994 \\
\hline 20.0200005 & 15.8699999 & 12.6899996 & 10.1300001 & 7.8130002 \\
\hline 6.1030002 & 5.0539999 & 3.9059999 & 3.296 & 2.4560001 \\
\hline 2.0239999 & 1.607 & 1.275 & 1.013 & 0.8047 \\
\hline 0.639 & 0.5072 & 0.408 & 0.33 & 0.2588 \\
\hline 0.2018 & 0.1602 & 0.1268 & 0.1009 & 0.0801 \\
\hline 0.0633 & 0.0504 & 0.0401 & 0.0319 & 0.0254 \\
\hline 0.02 & 0.0158 & 0.0126 & 0.0099 & 0.0078 \\
\hline 0.0061 & 0.0048 & 0.0038 & 0.0031 & 0.0023 \\
\hline
\end{tabular}

Figure A5H. Impedance polar plots for magnetotelluric station 45 (fig. 2). North $\left(0^{\circ}\right)$ is up. Green line is Zxy. Orange line is Zxx. Straight black line is rotation angle $\left(-78^{\circ}\right)$. Numbered label at each diagram bottom is frequency in Hertz. 


\section{Station 39}

\begin{tabular}{|c|c|c|c|c|}
\hline 195.3000031 & 160.8999939 & 128.3999939 & 101.5999985 & 80.3199997 \\
\hline 64.2099991 & 51.0299988 & 40.2799988 & 31.9799995 & 25.3899994 \\
\hline 20.0200005 & 15.8699999 & 12.6899996 & 10.1300001 & 7.8130002 \\
\hline 6.3720002 & 5.0539999 & 3.9059999 & 3.174 & 2.5880001 \\
\hline 2.197 & 2.0020001 & 1.607 & 1.275 & 1.013 \\
\hline 0.8047 & 0.639 & 0.4883 & 0.408 & 0.33 \\
\hline 0.2588 & 0.2018 & 0.1602 & 0.1268 & 0.1009 \\
\hline 0.0801 & 0.0633 & 0.0504 & 0.0401 & 0.0319 \\
\hline 0.0254 & 0.02 & 0.0158 & 0.0126 & 0.0099 \\
\hline 0.0078 & 0.0061 & 0.0048 & 0.0038 & 0.0031 \\
\hline
\end{tabular}

Figure A5I. Impedance polar plots for magnetotelluric station 39 (fig. 2). North $\left(0^{\circ}\right)$ is up. Green line is Zxy. Orange line is Zxx. Straight black line is rotation angle $\left(-78^{\circ}\right)$. Numbered label at each diagram bottom is frequency in Hertz. 


\section{Station 48}

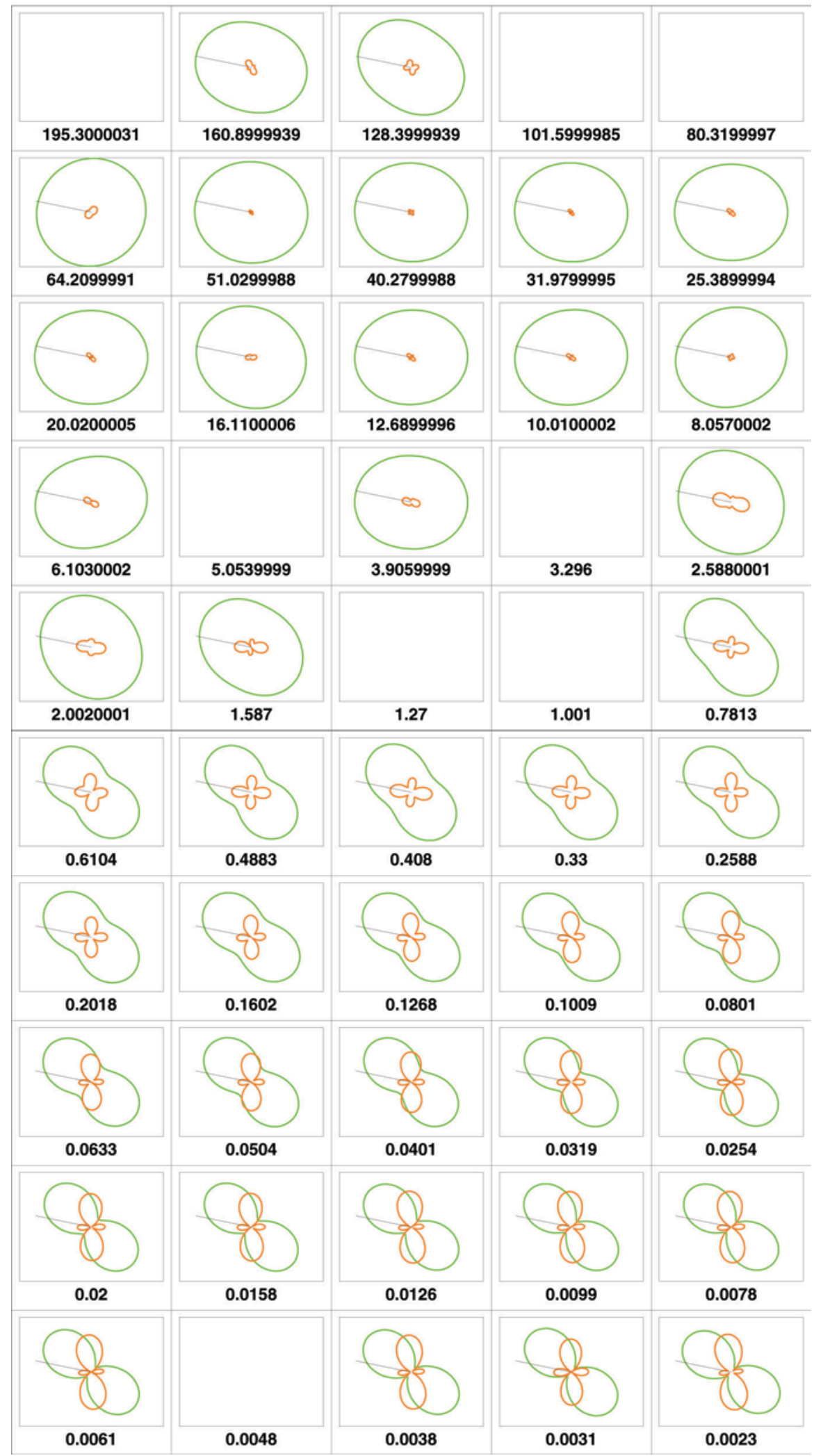

Figure A5J. Impedance polar plots for magnetotelluric station 48 (fig. 2). North $\left(0^{\circ}\right)$ is up. Green line is Zxy. Orange line is Zxx. Straight black line is rotation angle $\left(-78^{\circ}\right)$. Numbered label at each diagram bottom is frequency in Hertz. 


\section{Station 37}

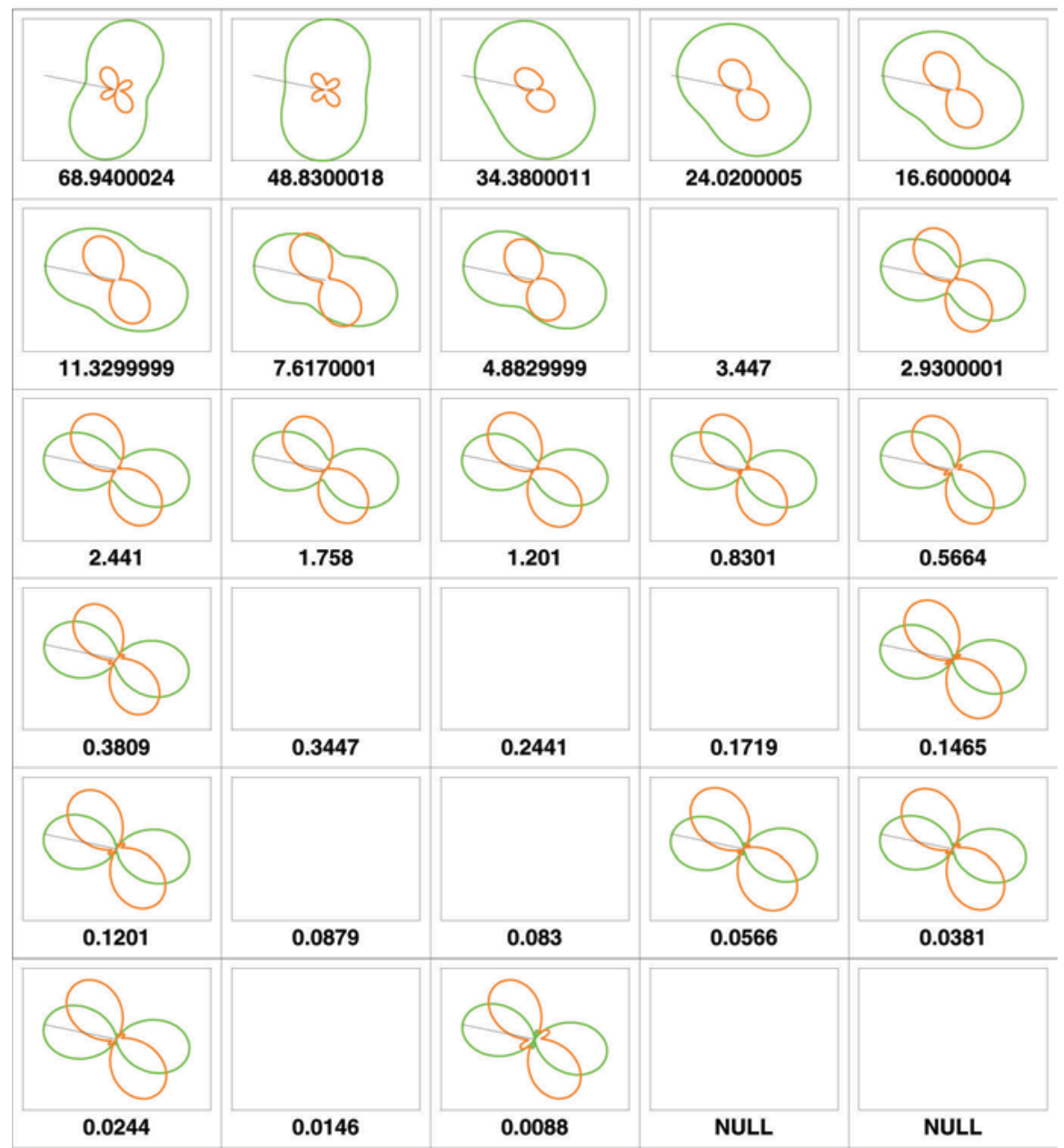

Figure A5K. Impedance polar plots for magnetotelluric station 37 (fig. 2). North $\left(0^{\circ}\right)$ is up. Green line is Zxy. Orange line is Zxx. Straight black line is rotation angle $\left(-78^{\circ}\right)$. Numbered label at each diagram bottom is frequency in Hertz. 


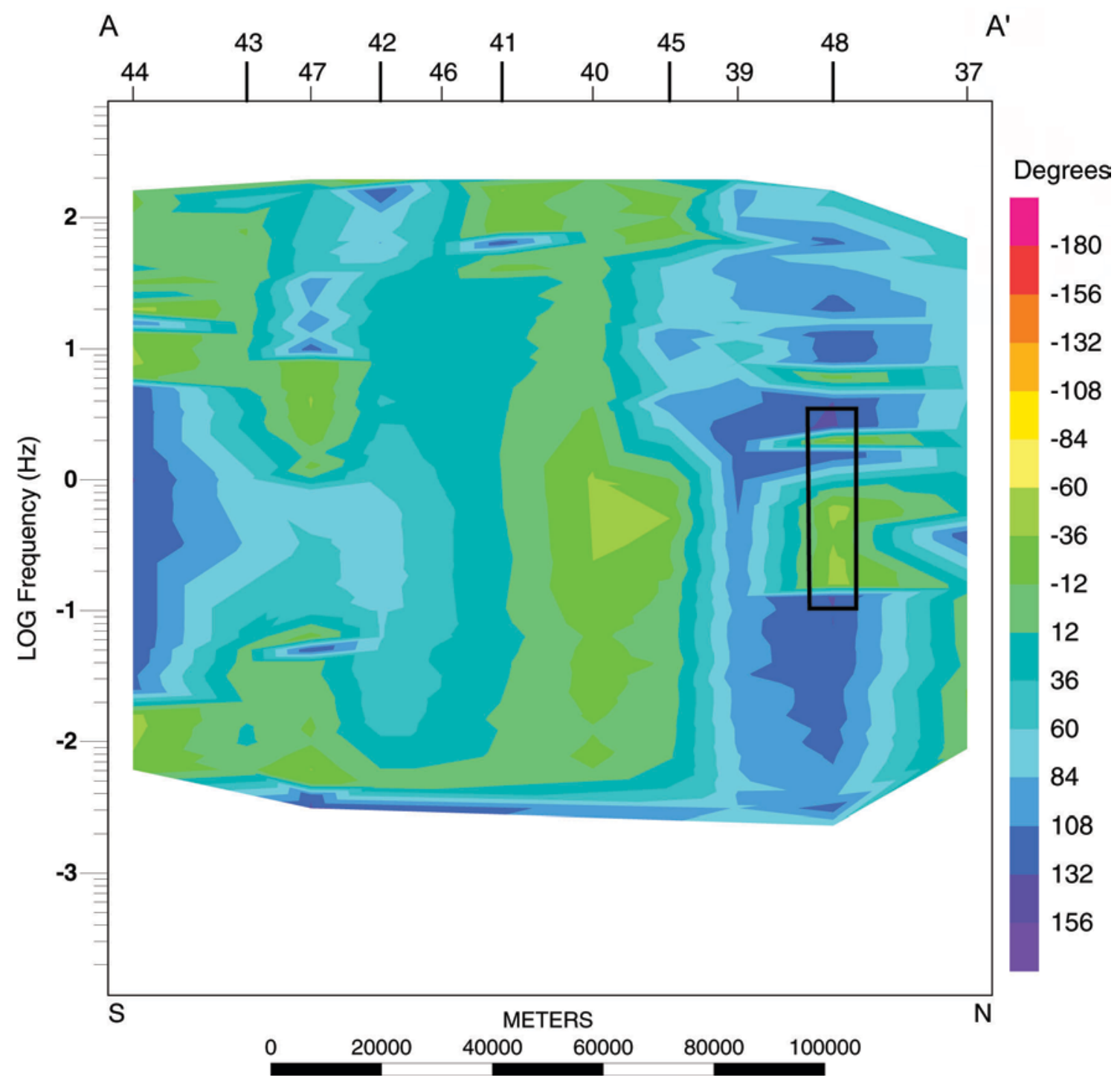

Figure A6. Tipper strike angle in degrees for profile A-A' (fig. 2). Black box delineates tipper strike angle for Cheyenne belt (Fig. 2). Numbered labels at figure top are magnetotelluric stations. 